\title{
1 A joint analysis of longevity and age-related disease variants for gene expression 2 association
}

3 Lu Zeng ${ }^{1}$, Shouneng Peng ${ }^{1}$, Seungsoo Kim, Jun Zhu ${ }^{1}$, Bin Zhang ${ }^{1}$, Yousin Suh $^{2}$, Zhidong Tu ${ }^{1 *}$

$4 \quad{ }^{1}$ Department of Genetics and Genomic Sciences, Icahn School of Medicine at Mount Sinai, NY.

$5 \quad{ }^{2}$ Department of Obstetrics and Gynecology, Columbia University, NY.

$6 \quad *$ Correspondence:

7 Zhidong Tu. Department of Genetics and Genomic Sciences, Icahn School of Medicine at Mount Sinai,

8 NY. Address: 1425 Madison Avenue, Box 1498, New York, NY, 10029-6574. Tel: +1 (212) 659-8508.

9 Fax: +1 (212) 659-1388, Email: zhidong.tu@ mssm.edu.

\section{Abstract}

12 A large number of genetic variants associated with human longevity have been reported but how

13 they play their functions remains elusive. We performed an integrative analysis on 113 genome-

14 wide significant longevity and 14,529 age-related disease variants in the context of putative gene

15 expression regulation. We found that most of the longevity allele types were different from the

16 genotype of disease alleles when they were localized at the same chromosomal positions.

17 Longevity variants were about eight times more likely to be associated with gene expression than

18 randomly selected variants. The directions of the gene expression association were more likely to

19 be opposite between longevity and disease variants when the association occurred to the same

20 gene. Many longevity variants likely function through down-regulating inflammatory response

21 and up-regulating healthy lipid metabolisms. In conclusion, this work helps to elucidate the

22 potential mechanisms of longevity variants for follow-up studies to discover methods to extend

23 human healthspan. 


\section{Introduction}

35 Longevity is a heritable trait and it was estimated that genetic factors account for approximately

$3620 \%$ to $30 \%$ of the variation in lifespan from twin studies (Herskind et al., 1996; Mitchell et al.,

37 2001). Although a very limited number of genetic factors have been replicated for association

38 with longevity, e.g., the ones near $A P O E$ and FOXO3, it is widely believed that longevity is

39 influenced by a large number of variants (Pilling et al., 2016) with most of them playing a small

40 effect on lifespan. Currently, hundreds of longevity variants have been reported (Melzer et al.,

41 2020) from association studies that were conducted on increasingly greater population sizes.

42 Validating these variants, elucidating their functions, and eventually translating the key findings

43 into actionable interventions have become an important but challenging task for human aging

44 research.

In addition to elucidating the determinant mechanisms of human lifespan, research on longevity could also shed light on the genetic regulation of age-related diseases. The relationship between longevity and age-related diseases is complex and remains to be fully elucidated. Although in general, long-lived individuals are healthier than their age-matched peers of average lifespan (Engberg et al., 2009), they are not free of age-related diseases. Actually, half of the centenarians age with at least one chronic disease and about one-fourth with disability (Ailshire et al., 2015).

53 frequencies of disease alleles (Beekman et al., 2010). Therefore, further identifying and

54 investigating the longevity variants that can prevent or slow the development of age-related

55 diseases will be of great importance for healthy aging research.

One strategy to study longevity variants is to experimentally interrogate the function of each variant (Flachsbart et al., 2017); although such approach is critical, it is time consuming and does not scale-up easily. It has been suggested that integrative data-driven approach may help us to

60 gain new insights into the validity and functionality of the longevity variants. For example, Dato

61 et al. performed a pathway-based SNP-SNP interaction analysis to investigate beyond the effect

62 of single SNP (Dato et al., 2018). In this work, we use data from GTEx (Genotype-Tissue 63 Expression) project to portray the landscape of genetic association with gene expression by 
64 jointly considering longevity and age-related disease variants. In particular, we ask a few key 65 questions, do longevity variants represent a distinct set of genetic factors from disease variants?

66 What fraction of longevity variants are likely to function through regulating gene expression in

67 human? And finally, when longevity and disease variant are both associated with a gene's 68 expression, will the associations be in the same or different directions? We believe addressing 69 these questions will help us to better understand longevity variants and their relationship with 70 disease variants.

\section{Results}

73 Longevity alleles are mostly different from disease alleles when they are localized at the 74 same chromosomal positions

75 To obtain a comprehensive list of longevity variants, we relied on three data sources, i.e., the 76 NHGRI-EBI GWAS Catalog (Buniello et al., 2019), LongevityMap (Budovsky et al., 2013) and 77 manually curated published studies, encompassing 90 GWA studies published from 1991 to 782019 (Fig. 1). In total, 3,674 genetic loci associated with longevity were collected from these 79 data sources. Among them, 113 longevity variants were genome-wide significant $\left(\mathrm{p} \leq 5 \times 10^{-8}\right)$, and 80104 of them were genotyped in the GTEx v8 data which contained genotype information for $8146,569,704$ SNPs (Supplemental Table S1).

83 We next investigated if the loci for these 113 longevity variants could also be associated with 84 age-related diseases. To do so, we downloaded genetic variants associated with 165 age-related 85 disease categories whose incidence rates increase exponentially with age (Jaul \& Barron, 2017) 86 from the NHGRI-EBI GWAS Catalog, covering diseases such as Alzheimer's disease, type 2 87 diabetes, hypertension and cancers. Similar to longevity variants, we only retained disease 88 variants that were genome-wide significant $\left(\mathrm{p} \leq 5 \times 10^{-8}\right)$, we then removed disease variants whose 89 risk alleles were inconsistent within the same disease category (e.g., rs11257238 alleles T and C 90 were both annotated to increase the risk of Alzheimer's disease and were removed due to such 91 inconsistency (Jansen et al., 2019; Jun et al., 2017)), which resulted in a total number of 14,529 92 unique disease variants (Supplemental Table S2). Our results showed that 41\% (46/113) of our 93 longevity variants were also associated with these disease traits (Support Table 1). Not

94 surprisingly, we found that for these colocalized longevity alleles, their allele types were mostly 
95 different from the disease alleles (42 out of 46), while only four of them shared the same alleles

96 with disease traits, namely, rs429358, rs4420638, rs16991615 and rs3184504. Since in many

97 cases the longevity variants were identified independently from disease GWA studies which

98 relied on different cohorts and/or examined different traits, this indicates that a large proportion

99 of these 113 genome-wide significant longevity variants are likely real and biologically

100 meaningful despite they have been mostly unreproducible so far (otherwise, it will be nearly

101 impossible to observe such a high "reverse" overlap by random chance). For the four longevity

102 variants that shared the same alleles with disease, we found that the alternative alleles of the

103 longevity variants were often associated with some disease traits as well. rs429358, located in the

104 fourth exon of the $A P O E$ gene, causes amino acid change in APOE protein that leads to switch

105 from $A P O E \varepsilon 3 / \varepsilon 2$ to $\varepsilon 4$ (Rall et al., 1982). The longevity beneficial allele T (Pilling et al., 2017;

106 Timmers et al., 2019) is somehow associated with an increased risk for type 2 diabetes (Mahajan

107 Taliun, et al., 2018), while the alternative allele $\mathrm{C}$ is associated with an increased risk of AD and

108 AD-related measurements (such as amyloid-beta/p-tau/t-tau) (Moreno-Grau et al., 2019).

109 rs4420638, located in the APOC1 gene and 14kb downstream of the APOE $\varepsilon 4$ allele, has a strong

110 association with AD. It is in a strong linkage equilibrium (LD) with rs429358 (D'=0.86) (Nyholt

111 et al., 2009). The longevity allele A (Fortney et al., 2015; McDaid et al., 2017) was found to be

112 associated with increased age-related macular degeneration (AMD) risk (Fritsche et al., 2013);

113 while the alternative allele $\mathrm{G}$ was associated with increased risk of LDL, CAD, AD, and higher

114 all-cause mortality (Deelen et al., 2014). rs16991615 is a nonsynonymous SNP on chromosome

115 20. The longevity allele A (Bae et al., 2019) was also associated with increased risk of breast

116 cancer (Michailidou et al., 2017) and heavy menstrual bleeding (Gallagher et al., 2019).

117 rs3184504 is a nonsynonymous SNP in the SH2B3 gene. The longevity allele C (Pilling et al.,

118 2017) was associated with an increased risk of colorectal cancer while the alternative allele $\mathrm{T}$

119 was associated with an increased risk of CAD (Schunkert et al., 2011) and stroke (Malik et al.,

120 2018).

122 Among the 46 colocalized variants, 37 (>80\%) were eQTLs in the GTEx data, while only $7.8 \%$ 123 of randomly selected GTEx SNPs were eQTLs (see details in the next section), indicating 124 longevity variants co-localized with disease traits are highly enriched for loci associated with 125 gene expression. 
132 Figure 1

A

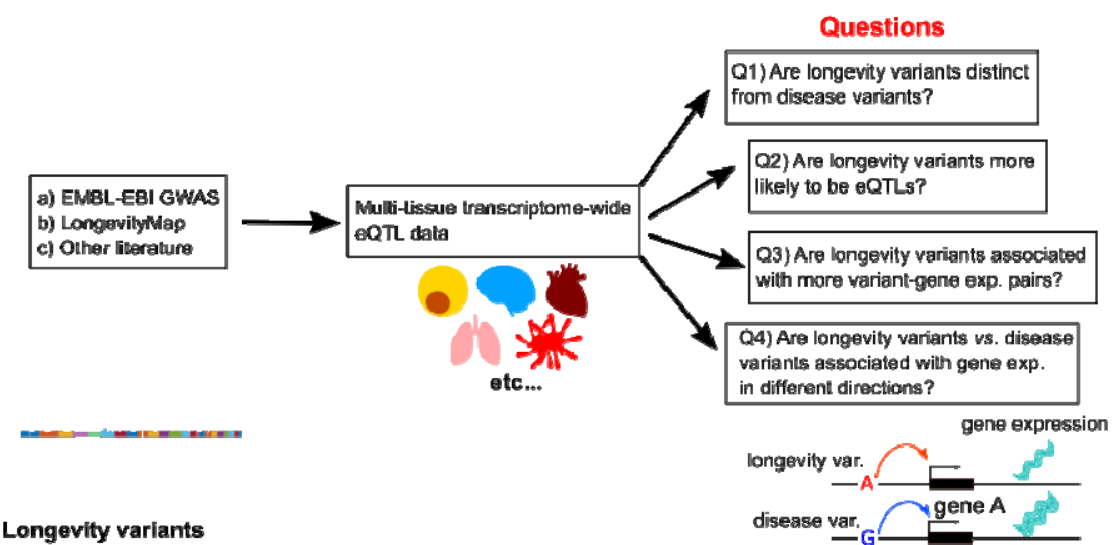

B Longevity variants

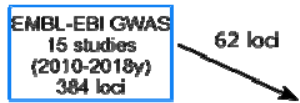

Longevilytap Fiter (p-value $<=5$ e-08) 3.028 lod

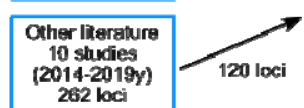

10 shucies
(2014-2019y) 262 loci

Disease variants fitter (p-value $<=50-08$ )

\begin{tabular}{c|c|}
\hline EMBL-EBI GWAS \\
186 age-related diseases \\
46,427 disease variants
\end{tabular}$\longrightarrow \begin{gathered}165 \text { age-related diseases } \\
14.529 \text { unique disease variants }\end{gathered}$

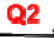

104 unique longevity aQTLs 46,427 disaase variants

A. An overflow of the study. We highlight the key questions which we address by comparing longevity and disease variants in the context of gene expression association. B. Additional information on data input and the analytical pipeline, questions Q1 to Q4 correspond to the questions in A.

\section{Longevity variants are significantly more likely to be associated with gene expression}

139 In GTEx data, 67 longevity variants were associated with 183 unique genes' expression (also

140 known as eQTL-eGene pairs) in 47 GTEx tissues (false discovery rate (FDR) $\leq 0.05$ ), which

141 corresponded to a total of 1,793 eQTL-eGene pairs. This reduced to 326 unique variant-gene 
142 pairs if we did not consider tissue specificity, i.e., by counting the same eQTL-eGene pair across

143 different tissues as one pair (Support Table $2 \&$ Supplemental Table 3).

145 Permutation test was used to assess if the observed number of longevity eQTLs would occur by

146 random chance. Since 104 of 113 longevity variants were genotyped in the GTEx v8 data, we

147 randomly selected 104 variants from all the 46,569,704 GTEx SNPs for 1,000 times (without

148 replacement) and counted how many of them were eQTLs. Compared to 67 out of 104 longevity

149 variants that were eQTLs, in the permutation runs, on average, 8.4 randomly selected variants

150 were eQTLs, with a standard deviation (SD) of 3.34. This indicates that longevity variants are

151 significantly more likely to be associated with gene expression compared to random SNPs (Fig.

152 2A, permutation test, mean $=8.4, \mathrm{SD}=3.34, \mathrm{p} \leq 1.0 \times 10^{-3}$ ).

154 Similarly, to estimate the significance of the observed number of longevity variant-gene 155 expression pairs, we randomly selected 67 GTEx eQTLs for 1,000 times, and calculated the

156 number of variant-gene expression pairs for these eQTLs across 47 GTEx tissues. The 157 permutation analysis revealed that 67 randomly selected eQTLs were involved in an average of 1581021.4 variant-gene expression pairs $(\mathrm{SD}=311.90)$, compared to 1,793 longevity variant-gene 159 pairs (empirical $\mathrm{p}=0.025$ ). When we did not consider the tissue specificity of the eQTLs, the 160 permutation runs identified 198.1 \pm 30.68 (mean \pm SD) variant-gene pairs, which is significantly 161 less than the observed 326 longevity variant-gene pairs (empirical $\mathrm{p} \leq 1.0 \times 10^{-3}$ ). This result 162 suggests that longevity eQTLs were significantly associated with more eGenes in GTEx than 163 randomly selected eQTLs (Fig. 2B). 

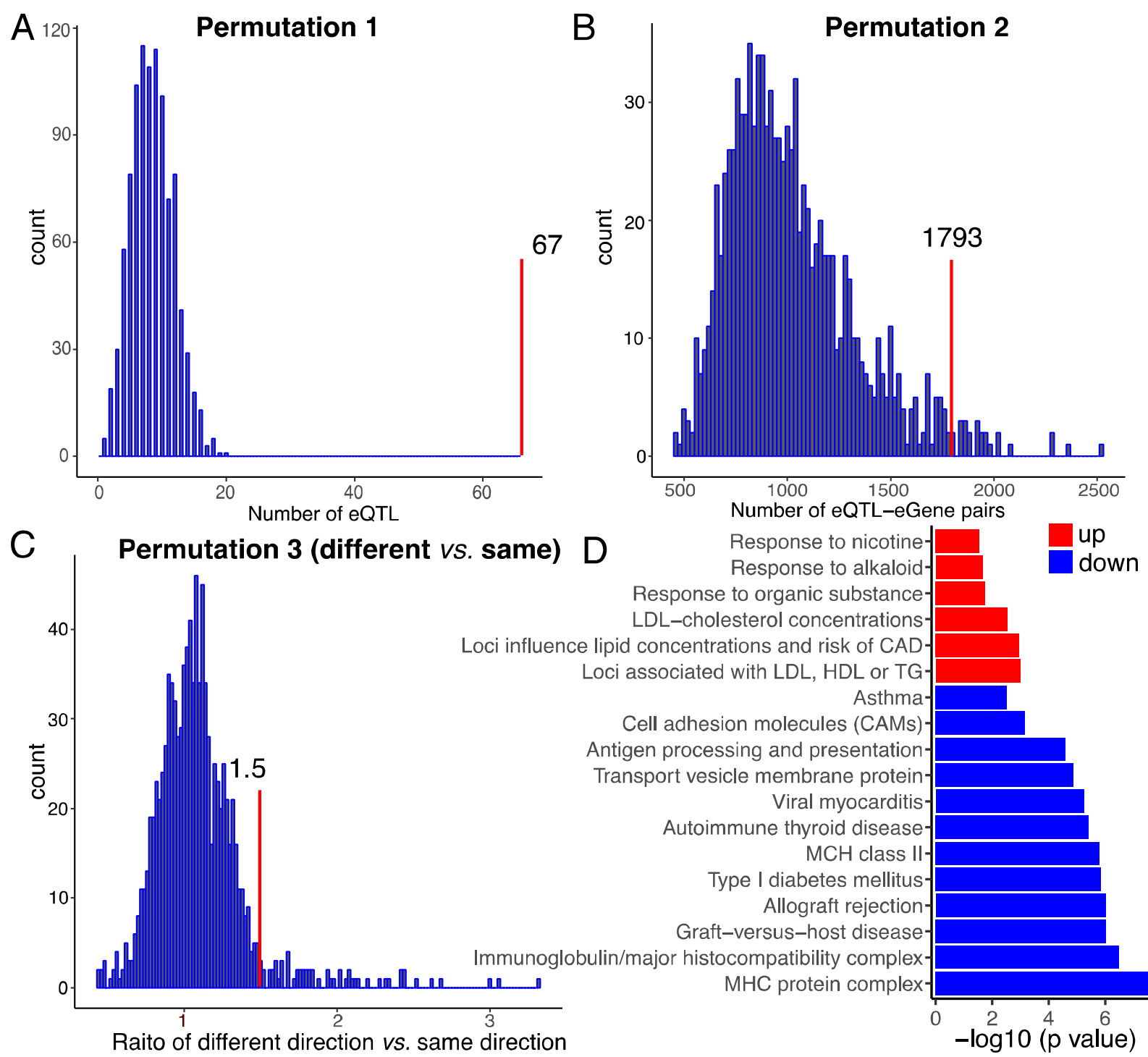

Response to organic substance-

LDL-cholesterol concentrations Loci associated with LDL, HDL or TG-

AsthmaAntigen processing and presentation Transport vesicle membrane proteinViral myocarditis Autoimmune thyroid disease$\mathrm{MCH}$ class $\|$ Type I diabetes mellitus Allograft rejectionGraft-versus-host diseaseMHC protein complex Raito of different direction vs. same direction

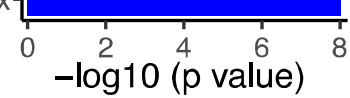

Permutation tests were performed to evaluate (a) if longevity variants were more likely to be eQTLs compared with randomly selected SNPs, (b) if longevity variants were involved in more variant-gene expression association pairs compared with randomly selected eQTLs, (c) the ratio $=\frac{\# \text { different association directions }}{\text { \#same association directions }}$ indicates if longevity variants were more likely to associate with gene expression in the opposite direction from disease alleles when they both were associated with same gene expression in subcutaneous fat, and (d) functional enrichment of longevity-variants associated eGenes.

174 Longevity variants associated up- and down- regulated eGenes were involved in distinct

\section{5 functions}

176 We next investigated the function of eGenes that were associated with longevity variants. We 177 only focused on eQTLs showing relatively consistent association directions with gene expression 178 across GTEx tissues and we considered up- and down- regulated eGenes separately. In particular, 179 we kept eQTL-eGene pairs if their directions were consistent across $\geq 60 \%$ GTEx tissues, and 
the expression direction of these eGenes were determined by the majority directions $(\geq 60 \%)$.

181 For instance, longevity variant rs72738736 allele G (Pilling et al., 2017) showed opposite 182 association with iron responsive element binding protein 2 (IREB2) gene expression in two

183 tissues: whole blood (higher gene expression) and testis (lower gene expression) (Support Table

184 2). Since there is no simply way to determine which associations are biologically meaningful, we

185 removed this eQTL-eGene pair for further analysis and only focus on those eQTLs showing an

186 apparent dominant association direction.

Based on GTEx significant variant-gene expression associations (FDR $\leq 0.05$ ), a slightly higher proportion of the longevity alleles were associated with increased gene expression. For example, 67 longevity eQTLs were found associated with 1,751 variant-gene pairs, and 944 of them were associated with higher gene expression with longevity alleles, corresponding to 94 unique genes, while 807 of them were down-associated with longevity alleles, corresponding to 89 unique genes. When we did not count the tissue specificity, the total number of variant-gene pairs reduced to 317 and among them, 167 were up, and 150 were down for the association with

197 We then inspected the function enrichment for genes associated with longevity variants using 198 DAVID tools (Huang da et al., 2009). GO annotation and pathway analysis demonstrated 199 differential function enrichment between up- and down-associated genes with longevity variants. 200 Among genes down-associated with longevity variants, they were characterized for MHC protein 201 complex $\left(\right.$ Benjamini-Hochberg $\left.(\mathrm{BH})=9.19 \times 10^{-9}\right)$, immunoglobulin $\left(\mathrm{BH}=3.23 \times 10^{-7}\right)$ and antigen 202 processing $\left(\mathrm{BH}=2.59 \times 10^{-5}\right)$. On the other hand, genes up-associated with longevity variants were 203 enriched for functions such as response to blood low-density lipoprotein cholesterol, high204 density lipoprotein or triglycerides in humans $\left(\mathrm{BH}=1.03 \times 10^{-3}\right)$, and newly identified loci that 205 influence lipid concentrations and risk of coronary artery disease $\left(\mathrm{BH}=1.07 \times 10^{-3}\right)$ (Figure $2 \mathrm{D}$, a 206 full list of functional annotations is provided in Supplemental Table S4). This result suggests that 207 longevity variants could play their beneficial roles through down-regulating the inflammatory 208 response and up-regulating healthy lipid metabolisms. 
210 The association directions were more likely to be opposite when longevity and disease 211 variants were associated with same gene's expression

212 We wanted to obtain a global view of the potential gene expression regulation by longevity

213 variants and compare that with 14,529 unique age-related disease variants as aforementioned.

215 To examine the potential influence of longevity and disease variants on gene expression, we 216 focused on eGenes whose expression was simultaneously associated with at least one disease and 217 one longevity variant in GTEx data. Using GTEx subcutaneous fat tissue as an example, 30 218 longevity variants were associated with 60 genes' expression, corresponding to 92 longevity 219 variant-gene expression pairs. 360 unique disease variants from 76 disease traits were also 220 associated with these 60 genes' expression, forming a total of 1,513 unique longevity variant221 gene expression-disease variant trios. We then inspected the association directions between the 222 gene expression of these 60 genes with disease $v s$. longevity variants. The comparison showed 223 that the direction of association with gene expression for longevity alleles were different from 224 disease alleles for 931 unique variant-gene-variant trios. For example, the longevity beneficial 225 allele $\mathrm{G}$ of rs3130507 (Pilling et al., 2017) was associated with lower expression of transcription 226 factor 19 (TCF19), while type 2 diabetes variants rs2073721 (Mahajan Wessel, et al., 2018) was 227 associated with an increased TCF19 gene expression in GTEx adipose tissue. TCF19's mRNA 228 expression has been reported to increase in nondiabetic obesity (Krautkramer et al., 2013). In 229 contrast, 621 unique variant-gene-variant trios showed same gene expression association 230 direction with longevity vs. disease alleles. For example, as we mentioned above, longevity 231 variants rs3130507 was associated with down-regulated gene expression of TCF19, while the 232 allele G of rs3094013, a SNP associated with increased body mass index (Graff et al., 2017) was 233 also associated with decreased TCF19 gene expression in GTEx adipose tissue.

235 For nine genes, their gene expression associations with longevity vs. disease alleles were 236 consistently in the opposite direction in GTEx subcutaneous fat. These include FES proto237 oncogene, tyrosine kinase (FES), neutrophil cytosolic factor 1C pseudogene (NCF1C), 238 NOP2/sun RNA methyltransferase 5 pseudogene 1 (NSUN5P1), PMS1 homolog 2, mismatch 239 repair system component pseudogene 2 (PMS2P2), PMS1 homolog 2, mismatch repair system 240 component pseudogene 3 (PMS2P3), POM121 transmembrane nucleoporin C (POM121C), 
241 speedy/RINGO cell cycle regulator family member E5 (SPDYE5), and stromal antigen 3-like 1

242 (pseudogene) (STAG3L1). Seven of these genes showed decreased gene expression association

243 with longevity alleles, except for FES and PMS2P3 which showed increased gene expression.

244 The FES expression was down-regulated in colorectal cancer cell lines (Shaffer \& Smithgall,

245 2009).

247 Similarly, we performed a permutation test to evaluate the significance of observing more 248 opposite associations with gene expression between longevity and disease variants. Since 30 249 longevity variants were involved in 92 variant-gene pairs in subcutaneous fat, we randomly 250 selected 30 eQTLs for 1,000 times from GTEx subcutaneous adipose tissue while we ensured 251 that these variants were involved in 92 variant-gene pairs in each run (see details in Methods).

252 We then extracted GTEx adipose eGenes associated with these 30 eQTLs to pull out all the 253 variants that were associated with these eGenes; by overlapping these variants with disease 254 variants from the 165 disease categories, we then checked the direction of association between 255 disease alleles and longevity alleles for the corresponding eGenes. From this permutation 256 analysis, we observed a slightly more variant-gene expression-variant trios in the opposite 257 association directions, as the mean value of the ratio between opposite direction of association

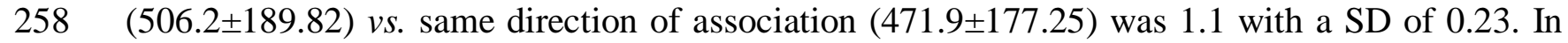
259 the real data, this ratio was 1.5 (931 associations in opposite directions between longevity vs. 260 disease alleles, and 621 associations in the same direction), suggesting longevity and disease 261 variants are significantly more likely to associate with a gene's expression in the opposite 262 directions (empirical $\mathrm{p}=0.042$ ).

264 Next, we expanded this analysis to all the other 46 GTEx tissues; we found that 3,148 unique 265 longevity variant-gene expression-disease variant trios showed opposite associations between 266 longevity and disease alleles, while 1,971 unique longevity variant-gene expression-disease 267 variant trios had same association direction, leading to a ratio of 1.6. Twenty eGenes consistently 268 showed opposite gene expression association between longevity and disease alleles (Table 1), 269 including two genes (NSUN5P1 and POM121C) identified from subcutaneous fat and 18 other 270 genes, which are AP4B1-AS1, AREL1, CIB4, FURIN, CASTOR2, GULOP, KCNK3, KLHDC10, 
272 ZC3HCl (detailed information can be found in support table 3).

\section{Table 1. List of genes whose expression associated with longevity and disease variants in} consistent opposite directions across 47 GTEx tissues.

We identified twenty genes whose association of their gene expression with longevity and disease alleles were consistently in the opposite directions. The third column shows the longevity eQTL for each gene and the beneficial allele. The fourth column shows the association direction with the longevity variant. The fifth column denotes the disease eQTLs and the risk alleles; the sixth column is the association direction with the disease variant; the last column shows the number of GTEx tissues in which such opposite associations were observed.

281

\begin{tabular}{|c|c|c|c|c|c|c|}
\hline $\begin{array}{l}\text { Gene } \\
\text { symbol }\end{array}$ & Gene name & $\begin{array}{l}\text { Longevity } \\
\text { variant and } \\
\text { allele type }\end{array}$ & $\begin{array}{l}\text { Exp } \\
\text { dir }\end{array}$ & $\begin{array}{l}\text { Disease } \\
\text { variant and } \\
\text { allele type }\end{array}$ & $\begin{array}{l}\text { Exp } \\
\text { dir }\end{array}$ & $\begin{array}{l}\text { No. of } \\
\text { GTEx } \\
\text { tissues }\end{array}$ \\
\hline$A P 4 B 1-A S 1$ & $\begin{array}{l}\text { Adaptor related protein complex } 4 \text { subunit } \\
\text { beta } 1 \text { antisense RNA } 1\end{array}$ & rs1230666:G & higher & $\begin{array}{l}\text { rs1230666:A } \\
\text { rs7513707: A } \\
\text { rs11552449:T }\end{array}$ & lower & 2 \\
\hline ARELI & $\begin{array}{l}\text { Apoptosis resistant E3 ubiquitin protein } \\
\text { ligase } 1\end{array}$ & rs61978928:C & lower & rs2165197:C & higher & 1 \\
\hline CIB4 & $\begin{array}{l}\text { Calcium and integrin binding family } \\
\text { member } 4\end{array}$ & rs1275922:G & lower & $\begin{array}{l}\text { rs1275984:A } \\
\text { rs1275982:C } \\
\text { rs1731249:T } \\
\text { rs1275978:C } \\
\text { rs1731243:C } \\
\text { rs1275988:C } \\
\text { rs11126666:A }\end{array}$ & higher & 1 \\
\hline FURIN & $\begin{array}{l}\text { Furin, paired basic amino acid cleaving } \\
\text { enzyme }\end{array}$ & rs6224:G & lower & $\begin{array}{l}\text { rs17514846:A } \\
\text { rs2071382:T } \\
\mathrm{rs} 2521501: \mathrm{T} \\
\mathrm{rs} 4932371: \mathrm{C} \\
\mathrm{rs} 4932373: \mathrm{C} \\
\mathrm{rs} 8039305: \mathrm{C}\end{array}$ & higher & 3 \\
\hline CASTOR2 & $\begin{array}{l}\text { Cytosolic arginine sensor for MTORC1 } \\
\text { subunit } 2\end{array}$ & rs113160991:G & higher & rs6944634:G & lower & 1 \\
\hline GULOP & Gulonolactone L- oxidase, pseudogene & rs7844965:G & higher & $\begin{array}{l}\text { rs2279590:C } \\
\text { rs11136000:C } \\
\text { rs4236673:G } \\
\text { rs1532278:C }\end{array}$ & lower & 1 \\
\hline KCNK3 & $\begin{array}{l}\text { Potassium two pore domain channel } \\
\text { subfamily K member } 3\end{array}$ & rs1275922:G & higher & $\begin{array}{l}\text { rs11126666:A } \\
\text { rs1275978:C } \\
\text { rs1275982:A } \\
\text { rs1275984:A } \\
\text { rs1275988:C } \\
\text { rs1731243:C } \\
\text { rs1731249:T }\end{array}$ & lower & 3 \\
\hline KLHDC10 & Kelch domain containing 10 & rs56179563:A & higher & rs11556924:C & lower & 1 \\
\hline NSUN5P1 & $\begin{array}{l}\text { NOP2/Sun RNA methyltransferase } 5 \\
\text { pseudogene } 1\end{array}$ & rs113160991:G & lower & $\begin{array}{l}\text { rs6963105:G } \\
\text { rs6944634:G } \\
\text { rs1167821:T } \\
\text { rs1167827:G } \\
\text { rs1167796:G }\end{array}$ & higher & 36 \\
\hline$P B X 2$ & PBX homeobox 2 & rs28383322:T & lower & $\begin{array}{l}\text { rs2071288:C } \\
\text { rs9268856:C }\end{array}$ & higher & 1 \\
\hline
\end{tabular}




\begin{tabular}{|c|c|c|c|c|c|c|}
\hline & & & & rs41268896:A & & \\
\hline PHTF1 & $\begin{array}{l}\text { Putative homeodomain transcription } \\
\text { factor } 1\end{array}$ & rs $1230666: G$ & higher & $\begin{array}{l}\text { rs1230666:A } \\
\text { rs7513707:A } \\
\text { rs11552449:T }\end{array}$ & lower & 3 \\
\hline PMS2 & $\begin{array}{l}\text { PMS1 homolog 2, mismatch repair } \\
\text { system component }\end{array}$ & rs1830074:C & lower & $\begin{array}{l}\text { rs1830074:C } \\
\text { rs7456039:C }\end{array}$ & higher & 1 \\
\hline$P M S 2 C L$ & PMS2 C-terminal like pseudogene & rs $3764814: C$ & higher & rs1830074:C & lower & 2 \\
\hline POM121C & POM121 transmembrane nucleoporin C & rs113160991:G & lower & $\begin{array}{l}\mathrm{rs} 6963105: \mathrm{G} \\
\mathrm{rs} 6944634: \mathrm{G} \\
\mathrm{rs} 1167821: \mathrm{T} \\
\mathrm{rs} 1167827: \mathrm{G} \\
\mathrm{rs} 1167796: \mathrm{G} \\
\mathrm{rs} 34324971: \mathrm{A}\end{array}$ & higher & 24 \\
\hline RGS12 & Regulator of $\mathrm{G}$ protein signaling 12 & rs61348208:T & higher & $\begin{array}{l}\text { rs362275:C } \\
\text { rs3121419:C } \\
\text { rs363066:T }\end{array}$ & lower & 2 \\
\hline$S L C 22 A 1$ & Solute carrier family 22 member 1 & $\begin{array}{l}\text { rs1510224:T } \\
\text { rs111333005:G }\end{array}$ & higher & $\begin{array}{l}\text { rs3798220:C } \\
\text { rs9295128:T } \\
\text { rs140570886:C } \\
\text { rs186696265:T } \\
\text { rs2297374:C } \\
\end{array}$ & lower & 7 \\
\hline SPDYE12P & $\begin{array}{l}\text { Speedy/RINGO cell cycle regulator } \\
\text { family member E12, pseudogene }\end{array}$ & rs113160991:G & lower & $\begin{array}{l}\text { rs35005436:C } \\
\text { rs6944634:G }\end{array}$ & higher & 1 \\
\hline TOMM40 & $\begin{array}{l}\text { Translocase of outer mitochondrial } \\
\text { membrane } 40\end{array}$ & rs71352238:T & lower & $\begin{array}{l}\text { rs34342646:A } \\
\text { rs71352238:C } \\
\text { rs10119:A }\end{array}$ & higher & 1 \\
\hline USP28 & Ubiquitin specific peptidase 28 & rs61905747:A & higher & rs61904987:T & lower & 1 \\
\hline $\mathrm{ZC} 3 \mathrm{HCl}$ & Zinc finger C3HC-type containing 1 & rs56179563:A & lower & rs11556924:C & higher & 2 \\
\hline
\end{tabular}

\section{Longevity eQTLs from GTEx were replicable in independent studies}

285 To evaluate the robustness of GTEx eQTLs, we collected eQTL-eGene pairs from six

286 independent eQTL studies which covered five tissues: adipose (MUTHER) (Nica et al., 2011),

287 brain cortex (ROSMAP) (Ng et al., 2017), heart left ventricle (Koopmann et al., 2014), lung

288 (Hao et al., 2012) and two blood studies (Võsa et al., 2018; Westra et al., 2013). We compared

289 eQTLs from these independent studies with the eQTLs identified in the corresponding GTEx

290 tissues. The comparison showed that eQTLs from these studies were highly enriched in GTEx

291 data. For example, 37\% adipose eQTLs from the MUTHER study were reproducible in GTEx

292 subcutaneous fat; for two blood eQTL studies, 44\% of the eQTLs from Võsa's work and $61 \%$ of

293 the blood eQTLs from Westra's work matched with GTEx whole blood eQTLs. For eQTL-

294 eGene pairs, a tissue-specific enrichment pattern could be seen for each tissue. For example,

295 GTEx subcutaneous fat had the most matching eQTL-eGene pairs with the adipose MUTHER

296 study (>2,000 pairs), while it had much fewer pairs in GTEx brain cortex (893 pairs). Similarly, 
4,278 eQTL-eGene pairs from the independent lung eQTL study were found replicated in the

298 GTEx lung, but much fewer pairs were found in other tissues (Supplemental Table S5). In

299 addition, we found most of the reproducible variant-gene pairs showed same direction in eQTL-

300 gene expression between independent studies and GTEx (Supplemental Table S5). For instance,

301 in blood tissue, 1,073,253 variant-gene pairs showed the same direction in eQTL-gene

302 expression association between GTEx and independent studies, only 123,723 pairs showed

303 different directions. For the following analysis, we only considered the variant-gene expression

304 pairs that showed the same association direction between GTEx and those independent studies.

We then repeated part of our analyses with these replicated eQTL-eGene pairs. Our results showed that overall the eQTL-gene expression association directions were different between disease and longevity alleles in all five tissues, resulting 531 unique variant-gene-variant trios showed opposite directions, and 203 unique variant-gene-variant trios showed same directions (Supplemental Tables S6 \& 7), a ratio of 2.6 between the two. Since this ratio increased from 1.5

311 in subcutaneous fat, to 1.6 across 47 tissues, to 2.6 in replicated eQTL studies, this indicates that

312 the longevity and disease alleles are more likely to associate with gene expression in the opposite 313 directions when robust eQTLs are considered.

315 For these replicated eQTL-eGene pairs, we noticed that longevity alleles showed consistent 316 opposite association compared to disease alleles on eleven genes' expression, five of them were 317 replicated from our previous analysis (NCF1C, NSUN5P1, PMS2P3, RGS12 and SLC22A1), and 318 the rest are CHRNA5, HLA-B, MAPKAPK5, POU5F1, PBX2 and RNF5. In several cases, 319 longevity alleles were found to play a putative beneficial role with respect to the associated gene 320 expression (Table 2). For examples, longevity variant rs61348208 (Timmers et al., 2019) was 321 associated with higher RGS12 gene expression, while its expression level was relatively lower in 322 African American (AA) prostate cancer (Wang et al., 2017). Longevity variants rs3130507, 323 rs1510224 and rs186696265 (Pilling et al., 2017) were found to be associated with higher $324 S L C 22 A 1$ gene expression, while the expression of SLC22Al was down-regulated in 325 hepatocellular carcinoma (Okabe et al., 2001). Lower HLA-B gene expression was associated 326 with longevity variants rs3131621 and rs3130507 (Pilling et al., 2017), while the down- 
327 regulation of $H L A-B / C$ expression has been reported to correlate with a lower tumor stage and a

328 longer disease-free survival in colorectal cancer patients (Menon et al., 2002).

Table 2. Genes whose expression was associated with longevity vs. disease variants in opposite directions in multiple eQTL studies.

We identified eleven genes whose association of their gene expression with longevity and disease alleles were consistently in the opposite directions (gene symbols in bold-fonts are those replicated in GTEx data). The fourth column "Exp dir" shows the association direction of longevity alleles with each gene's expression; the last column is the putative beneficial expression direction of the corresponding genes based on previous studies, "unknown" indicates that no related expression studies were found for the corresponding gene.

\begin{tabular}{|c|c|c|c|c|c|c|}
\hline Gene symbol & Gene name & $\begin{array}{l}\text { Longevity } \\
\text { variant and } \\
\text { beneficial allele }\end{array}$ & $\begin{array}{l}\text { Exp } \\
\text { dir }\end{array}$ & $\begin{array}{l}\text { Disease } \\
\text { variant and } \\
\text { risk allele }\end{array}$ & $\begin{array}{l}\text { Expr } \\
\text { dir }\end{array}$ & Possible beneficial exp. dir \\
\hline CHRNA5 & $\begin{array}{l}\text { Cholinergic receptor } \\
\text { nicotinic alpha } 5 \\
\text { subunit }\end{array}$ & rs1317286:A & higher & $\begin{array}{l}\text { rs9788721:C } \\
\text { rs8034191:C } \\
\text { rs17486278:C } \\
\text { rs17487223:T } \\
\text { rs1317286:G } \\
\text { rs8031948:T } \\
\text { rs10519203:G } \\
\text { rs1051730:A } \\
\text { rs931794:G } \\
\text { rs2036527:A } \\
\text { rs16969968:A } \\
\text { rs7180002:T } \\
\text { rs951266:A } \\
\text { rs17483548:A } \\
\text { rs17405217:T }\end{array}$ & lower & $\begin{array}{l}\text { Low (Lung cancer studies } \\
\text { demonstrated up-regulation } \\
\text { of } C H R N A 5 \text { mRNA } \\
\text { expression in lung } \\
\text { adenocarcinomas, compared } \\
\text { to normal lung tissue } \\
\text { (Falvella et al., 2010)) }\end{array}$ \\
\hline$H L A-B$ & $\begin{array}{l}\text { Major } \\
\text { histocompatibility } \\
\text { complex, class I, B }\end{array}$ & $\begin{array}{l}\text { rs3131621:A } \\
\text { rs3130507:G }\end{array}$ & lower & $\begin{array}{l}\text { rs9378249:T } \\
\text { rs9378248:A }\end{array}$ & higher & $\begin{array}{l}\text { low (Down-regulation of } \\
H L A-B / C \text { expression } \\
\text { correlated with a lower } \\
\text { tumor stage and a longer } \\
\text { disease-free survival in } \\
\text { colorectal cancer patients } \\
\text { (Menon et al., 2002)) }\end{array}$ \\
\hline МАPKAPK5 & $\begin{array}{l}\text { MAPK activated } \\
\text { protein kinase } 5\end{array}$ & rs11066309:G & lower & $\begin{array}{l}\text { rs7305242:T } \\
\text { rs2301712:T } \\
\text { rs4766898:C }\end{array}$ & higher & $\begin{array}{l}\text { low (downregulating MK5 } \\
\text { expression inhibited the } \\
\text { survival of YAP-activated } \\
\text { cancer cell lines and mouse } \\
\text { xenograft model (Seo et al., } \\
\text { 2019)) }\end{array}$ \\
\hline NCF1C & $\begin{array}{l}\text { Neutrophil cytosolic } \\
\text { Factor } 1 \mathrm{C} \\
\text { pseudogene }\end{array}$ & rs113160991:G & lower & rs6944634:G & higher & $\begin{array}{l}\text { low (negligible } N C F 1 \\
\text { expression was identified in } \\
\text { chronic granulomatous } \\
\text { disease (Kuhns et al., 2019)) }\end{array}$ \\
\hline NSUN5P1 & $\begin{array}{l}\text { NSUN5 pseudogene } \\
1\end{array}$ & rs113160991:G & lower & $\begin{array}{l}\text { rs6963105:G } \\
\text { rs6944634:G } \\
\text { rs1167821:T } \\
\text { rs1167827:G } \\
\text { rs1167796:G }\end{array}$ & higher & Unknown \\
\hline$P B X 2$ & PBX homeobox 2 & rs28383322:T & lower & rs2071288:C & higher & high (reduction or absence \\
\hline
\end{tabular}




\begin{tabular}{|l|l|l|l|l|l|l|}
\hline & & & & $\begin{array}{l}\text { rs9268856:C } \\
\text { rs41268896:A }\end{array}$ & & $\begin{array}{l}\text { of PBX2 results in persistent } \\
\text { truncus arteriosus } \\
\text { (Stankunas et al., 2008) }\end{array}$ \\
\hline & $\begin{array}{l}\text { Putative postmeiotic } \\
\text { segregation } \\
\text { increased 2 } \\
\text { pseudogen 3 }\end{array}$ & rs113160991:G & higher & $\begin{array}{l}\text { rs6963105:G } \\
\text { rs6944634:G } \\
\text { rs1167821:T } \\
\text { rs1167827:G } \\
\text { rs1167796:G }\end{array}$ & lower & Unknown \\
\hline POU5F1 & $\begin{array}{l}\text { POU class 5 } \\
\text { homeobox 1 }\end{array}$ & rs3130507:G & lower & rs9378249:T & higher & $\begin{array}{l}\text { low (high POU5F1 } \\
\text { expression were } \\
\text { significantly more likely to } \\
\text { have a poor prognosis than } \\
\text { those with a low expression } \\
\text { in colorectal cancer patients } \\
\text { (Miyoshi et al., 2018)) }\end{array}$ \\
\hline RGS12 & $\begin{array}{l}\text { Regulator of G } \\
\text { protein signaling 12 }\end{array}$ & rs61348208:T & higher & $\begin{array}{l}\text { rs362275:C } \\
\text { rs3121419:C } \\
\text { rs363066:T }\end{array}$ & lower & $\begin{array}{l}\text { high (down-regulated in AA } \\
\text { prostate cancer (Wang et al., } \\
\text { 2017)) }\end{array}$ \\
\hline RNF5 & $\begin{array}{l}\text { Ring finger protein } \\
\text { 5 }\end{array}$ & rs3130507:G & higher & $\begin{array}{l}\text { rs3131378:G } \\
\text { rs501942:T } \\
\text { rs3131379:A } \\
\text { rs1150757:A }\end{array}$ & lower & $\begin{array}{l}\text { high (down-regulated in } \\
\text { body myositis (Delaunay et } \\
\text { al., 2008)) }\end{array}$ \\
\hline SLC22A1 & $\begin{array}{l}\text { Solute carrier family } \\
\text { 22 member 1 }\end{array}$ & $\begin{array}{l}\text { rs1510224:T } \\
\text { rs186696265:C }\end{array}$ & higher & $\begin{array}{l}\text { rs9295128:T } \\
\text { rs3798220:C } \\
\text { rs140570886:C } \\
\text { rs186696265:T }\end{array}$ & lower & $\begin{array}{l}\text { high (down-regulated in } \\
\text { hepatocellular carcinoma } \\
\text { (Okabe et al., 2001)) }\end{array}$ \\
\hline
\end{tabular}

\section{Discussion}

341 Thousands of genetic variants have been reported to be associated with human longevity 342 (Budovsky et al., 2013). Validation and follow-up studies on such a large number of longevity 343 variants remain to be challenging. For example, many of the variants are located in the non344 coding or intergenic regions and do not pin-point to a protein coding gene, how they may play 345 beneficial functions (if any) to human lifespan is elusive.

347 In this study, we collected 113 genome-wide significant longevity variants, and investigated their 348 relationship with age-related disease variants in the context of gene expression regulation. It is of 349 note that heterogeneous study designs were taken to identify the genetic determinants of human 350 longevity, e.g., population-based case and control cohorts (Fortney et al., 2015; Zeng et al., 351 2016), family-based cohorts to study parental survival trait (Joshi et al., 2017; Pilling et al., 2017) 352 and prospective studies (Broer et al., 2015; McDaid et al., 2017). Therefore, the longevity 353 variants compiled from these studies may point to different biology of aging and lifespan, even 354 though we collectively call them longevity variants. The heterogeneity in the derivation of 355 longevity variants could potentially complicate the interpretation of our results. 
357 We made several interesting observations in this work: first, from longevity GWA studies, not every hit may be beneficial for longevity, particularly if we are looking for variants responsible for healthspan. This is because some age-related diseases could be enriched in very long-lived individuals, such as the AMD. Therefore, it is possible that some of the GWAS derived longevity variants are causally associated with these diseases and represent increased disease risks

362 although they are also associated with longer lifespan. Second, a large proportion of the genome-

363 wide significant longevity variants may represent true biological signals even though they have 364 been hardly replicated. This is supported by the fact that over $80 \%$ of the longevity variants 365 when colocalized with disease variants had different allele types from the disease risk alleles. 366 Since disease and longevity variants were often identified from independent studies and derived 367 based on very different traits, this suggests that many of the genome-wide significant longevity 368 variants are not random hits but convey biological signals. This is expected as long-lived people are less likely to develop age-related chronic conditions than their same-age peers, and they remain healthier longer into the old ages (Sebastiani et al., 2017; Wei et al., 2017). Third, we think that many longevity variants could play their functions through modulating underlying

372 gene expression. This is supported by the observation that longevity variants were about eight 373 times more likely to be eQTLs in the GTEx data compared with randomly selected SNPs. In 374 particular, we observed that when a gene expression is associated with both longevity and 375 disease variants, the association directions are more likely to be different than being the same. 376 This trend is more apparent when we narrowed down to those reproducible eQTL-eGene pairs 377 from independent studies. As a key goal of human aging and geroscience research is to identify 378 methods to promote human healthspan, this joint analysis provides a data-driven approach to 379 prioritize the longevity variants that may function through counteracting the effect of disease variants through gene regulation.

382 Although we observed that longevity and disease variants were often associated with a gene 383 expression in opposite directions, many of them also showed same direction in association with 384 gene expression. This could receive multiple explanations. First, reported genetic variants for 385 longevity and diseases may not always be accurate; in fact, some of the reported findings on these variants were inconsistent. For example, allele $\mathrm{T}$ of rs660240 was associated with 
increased heel bone mineral density based on the NHGRI-EBI GWAS Catalog, while it was also reported to associate with increased risk of osteoporosis in certain studies (Morris et al., 2019), while low bone mineral density (BMD) is the major determinant for osteopenia and osteoporosis (Cauley et al., 2007). Currently we largely relied on the GWAS catalog annotation since manually curating 14,529 SNPs will require an extraordinary amount of effort and in some cases impossible without full access to the original genotype/phenotype data; Second, some eQTL calls may not be robust; although we show they are largely consistent across different studies, there were some apparent variations in eQTL calling across studies; Third, eQTLs only indicate association between genetic variants and gene expression, it remains unknown if the eQTLs are actually involved in regulating the gene expression; this becomes even more complicated due to the fact that multiple mapping among variants-gene expression exists. For instance, rs602633 (Pilling et al., 2017) was associated with the PSRC1, SYPL2, CELSR2, SORT1 expression changes across 25 GTEx tissues, it is unclear which variant-gene expression association is biologically functional; last but not least, since it is not known for certain in which tissue(s) a variant plays its function, we may consider eQTLs that are actually not functional in the tissues under consideration. Recently, multiple statistical methods have been developed to facilitate the casual inference between genetic variant, gene expression and phenotypic outcome. For example, the COLOC is a Bayesian test to assess if two traits shared a causal variant (Giambartolomei et al., 2014), S-PrediXcan was developed to perform transcriptome-wide genome association to identify possible gene expression associated with the phenotypic traits (Jasinska, 2020), and transcriptome-wide summary statistics-based Mendelian randomization method TWMR was developed to use multiple SNPs as instruments and multiple gene expression traits as exposures to infer if the causal link between instruments and outcome was mediated by exposures (Porcu et 410 al., 2019). Although these methods are helpful to test the potential involvement of gene 411 expression in causing phenotypic trait, they all require GWAS summary statistics and therefore 412 limited their use in this study.

414 We noticed that two well-known longevity genes $A P O E$ and FOXO3 were not included in our 415 gene list as shown in Tables 1 and 2. Two common APOE alleles were found either significantly 416 depleted ( $\varepsilon 4$ allele) or enriched ( $\varepsilon 2$ allele) in long-lived individuals as compared to controls (Ryu 417 et al., 2016). The variants for both alleles are located in protein-coding regions and may not 
418 affect regulatory regions to impact gene expression. In fact, we found three of our longevity

419 variants (rs283811 (Sebastiani et al., 2017), rs7412 (Deelen et al., 2019) and rs4420638 (McDaid

420 et al., 2017)) were associated with APOE's gene expression only in GTEx skin tissues but not in

421 other tissues. Although FOXO3 has been identified to associate with longevity in human, none of

422 the reported SNPs reached genome-wide significant $\left(\mathrm{p} \leq 5 \times 10^{-8}\right)$ in our initial longevity variants

423 collection, therefore the longevity variants associated with FOXO3 were filtered out (Flachsbart

424 et al., 2009; Li et al., 2009; Willcox et al., 2008). In addition, none of our longevity variants were

425 significantly associated with FOXO3's gene expression in GTEx data.

427 Longevity is believed to be a highly polygenic phenotype and we have only examined a small

428 fraction of all possible longevity variants as we focused on genome-wide significant variants in

429 this study. We expect to see more longevity variants to emerge and to be replicated as genetic

430 information will be increasingly available from larger populations. This work therefore

431 establishes a new direction for further exploration to prioritize the longevity variants that could

432 be truly beneficial to extending human health span.

\section{Methods}

\section{Longevity and disease variants collection}

436 In order to get a comprehensive list of longevity variants, we went through three sources: 1)

437 LongevityMap: a database of human genetic variants associated with longevity, including 65

438 GWA studies carried out from 1991 to 2015, with 3,028 loci collected; 2) The NHGRI-EBI

439 GWAS Catalog: a curated collection of human genome-wide association studies, including 15

440 longevity GWAS studies with 384 loci; 3) last but not least, by going through recent longevity

441 studies that were not covered by either LongevityMap or the NHGRI-EBI GWAS Catalog. We

442 manually curated 262 longevity variants (Fig. 1). We only considered longevity variants with a

443 genome-wide significant p-value $\left(\leq 5 \times 10^{-8}\right)$, which resulted to 113 longevity variants with

444 reported beneficial alleles (Supplemental Table S1). 104 of these 113 longevity variants were

445 covered in GTEx genotype data. The 104 longevity variants were then intersected with

446 68,129,832 significant variant-gene expression associations (FDR $\leq 0.05$ ) identified in GTEx v8.

44767 longevity variants were found associated with 183 unique genes' expression, corresponding to

4481,793 variant-gene pairs across 47 tissues in a tissue-specific manner. 
450 Genetic variant information for 186 age-related diseases were downloaded from the NHGRI-EBI

451 Catalog (accessed on July 10, 2019), only variants reaching genome-wide significance $\left(\mathrm{p} \leq 5 \times 10^{-8}\right)$

452 with known risk alleles were kept. We removed disease variants whose risk alleles were

453 inconsistent within the same disease category. After filtering, a total of 14,529 unique variants

454 with respect to 165 disease traits were compiled for further analysis.

\section{Permutation test}

457 Permutation analyses were carried out to: 1) test if longevity variant is more likely to be an 458 eQTL; we randomly selected 104 variants from all SNPs genotyped in GTEx for 1,000 times, 459 and we checked for each run how many SNPs were associated with gene expression. Empirical 460 p-value was then calculated to estimate the significance of the observed number of eQTLs for 461 longevity variants; 2) test if longevity variants were involved in more variant-gene pairs than 462 randomly selected variants; we randomly selected 67 variants that were eQTLs in GTEx for 463 1,000 times, and counted how many variant-gene expression pairs were linked to these eQTLs in 464 GTEx, similarly, empirical p-value was then calculated to test the significance of observed 465 eQTL-eGene pairs for longevity variants; 3) finally, we tested the significance of the difference 466 between longevity vs. disease alleles on gene expression association direction. We used 467 subcutaneous fat as an example, 30 unique longevity variants were found to be associated with 46860 genes' expression, corresponding to 92 variant-gene pairs. To perform the permutation test, 469 we first randomly selected 30 GTEx eQTLs for 1,000 times that had same structures as longevity 470 eQTLs in subcutaneous fat. For example, 15 longevity variants were found to be associated with 471 only one gene's expression, while 6 longevity variants were associated with two genes' 472 expression in the adipose tissue and so on. GTEx eQTLs were thus randomly selected 473 accordingly based on the same structure in subcutaneous fat, i.e., to randomly select 15 eQTLs 474 that were associated with only one gene's expression, and 6 eQTLs that were associated with two 475 genes' expression, etc. In addition, 20 out of 30 longevity beneficial alleles were major alleles 476 for GTEx adipose, and 10 were minor alleles. We then randomly selected 20 major alleles and 10 477 minor alleles as longevity beneficial alleles in each random eQTL set. 
Six independent eQTL studies were downloaded to evaluate the robustness of GTEx eQTLs, covering five tissues: adipose (Nica et al., 2011), brain cortex ( $\mathrm{Ng}$ et al., 2017), left ventricle (Koopmann et al., 2014), lung (Hao et al., 2012) and two blood studies (Võsa et al., 2018; Westra et al., 2013). The reproducible variant-gene pairs between these studies and the corresponding GTEx tissues were then counted based on three criteria: 1) eQTLs from other studies were replicated in GTEx v8; 2) these replicated eQTLs associated with same eGene as in GTEx; 3) variant-gene pairs showed same association direction in eQTL-gene expression between independent studies and GTEx.

\section{Acknowledgements}

490 This work was funded by NIH grant R01AG055501 to Z.T. and Y.S. The content is solely the 491 responsibility of the authors and does not necessarily represent the official views of the National 492 Institutes of Health. This work was also supported in part through the computational resources 493 and staff expertise provided by Scientific Computing at the Icahn School of Medicine at Mount Sinai.

Competing interests

No competing interests declared.

\section{Reference}

Ailshire, J. A., Beltran-Sanchez, H., \& Crimmins, E. M. (2015, Feb). Becoming centenarians: disease and functioning trajectories of older US Adults as they survive to 100. J Gerontol A Biol Sci Med Sci, 70(2), 193-201. https://doi.org/10.1093/gerona/glu124

Bae, H., Lunetta, K. L., Murabito, J. M., Andersen, S. L., Schupf, N., Perls, T., Sebastiani, P., \& Long Life Family, S. (2019, Oct). Genetic associations with age of menopause in familial longevity. $\quad$ Menopause, 26(10), 1204-1212. https://doi.org/10.1097/GME.0000000000001367

Beekman, M., Nederstigt, C., Suchiman, H. E., Kremer, D., van der Breggen, R., Lakenberg, N., Alemayehu, W. G., de Craen, A. J., Westendorp, R. G., Boomsma, D. I., de Geus, E. J., Houwing-Duistermaat, J. J., Heijmans, B. T., \& Slagboom, P. E. (2010, Oct 19). Genome-wide association study (GWAS)-identified disease risk alleles do not compromise human longevity. Proc Natl Acad Sci U S A, 107(42), 18046-18049. https://doi.org/10.1073/pnas.1003540107 
Broer, L., Buchman, A. S., Deelen, J., Evans, D. S., Faul, J. D., Lunetta, K. L., Sebastiani, P., Smith, J. A., Smith, A. V., Tanaka, T., Yu, L., Arnold, A. M., Aspelund, T., Benjamin, E. J., De Jager, P. L., Eirkisdottir, G., Evans, D. A., Garcia, M. E., Hofman, A., Kaplan, R. C., Kardia, S. L., Kiel, D. P., Oostra, B. A., Orwoll, E. S., Parimi, N., Psaty, B. M., Rivadeneira, F., Rotter, J. I., Seshadri, S., Singleton, A., Tiemeier, H., Uitterlinden, A. G., Zhao, W., Bandinelli, S., Bennett, D. A., Ferrucci, L., Gudnason, V., Harris, T. B., Karasik, D., Launer, L. J., Perls, T. T., Slagboom, P. E., Tranah, G. J., Weir, D. R., Newman, A. B., van Duijn, C. M., \& Murabito, J. M. (2015, Jan). GWAS of longevity in CHARGE consortium confirms APOE and FOXO3 candidacy. J Gerontol A Biol Sci Med Sci, 70(1), 110-118. https://doi.org/10.1093/gerona/glu166

Budovsky, A., Craig, T., Wang, J., Tacutu, R., Csordas, A., Lourenco, J., Fraifeld, V. E., \& de Magalhaes, J. P. (2013, Oct). LongevityMap: a database of human genetic variants associated with longevity. Trends Genet, 29(10), 559-560. https://doi.org/10.1016/j.tig.2013.08.003

Buniello, A., MacArthur, J. A. L., Cerezo, M., Harris, L. W., Hayhurst, J., Malangone, C., McMahon, A., Morales, J., Mountjoy, E., Sollis, E., Suveges, D., Vrousgou, O., Whetzel, P. L., Amode, R., Guillen, J. A., Riat, H. S., Trevanion, S. J., Hall, P., Junkins, H., Flicek, P., Burdett, T., Hindorff, L. A., Cunningham, F., \& Parkinson, H. (2019, Jan 8). The NHGRI-EBI GWAS Catalog of published genome-wide association studies, targeted arrays and summary statistics 2019. Nucleic Acids Res, 47(D1), D1005-D1012. https://doi.org/10.1093/nar/gky1120

Cauley, J. A., Hochberg, M. C., Lui, L. Y., Palermo, L., Ensrud, K. E., Hillier, T. A., Nevitt, M. C., \& Cummings, S. R. (2007, Dec 19). Long-term risk of incident vertebral fractures. JAMA, 298(23), 2761-2767. https://doi.org/10.1001/jama.298.23.2761

Dato, S., Soerensen, M., De Rango, F., Rose, G., Christensen, K., Christiansen, L., \& Passarino, G. (2018, Jun). The genetic component of human longevity: New insights from the analysis of pathway-based SNP-SNP interactions. Aging Cell, 17(3), e12755. https://doi.org/10.1111/acel.12755

Deelen, J., Beekman, M., Uh, H. W., Broer, L., Ayers, K. L., Tan, Q., Kamatani, Y., Bennet, A. M., Tamm, R., Trompet, S., Guethbjartsson, D. F., Flachsbart, F., Rose, G., Viktorin, A., Fischer, K., Nygaard, M., Cordell, H. J., Crocco, P., van den Akker, E. B., Bohringer, S., Helmer, Q., Nelson, C. P., Saunders, G. I., Alver, M., Andersen-Ranberg, K., Breen, M. E., van der Breggen, R., Caliebe, A., Capri, M., Cevenini, E., Collerton, J. C., Dato, S., Davies, K., Ford, I., Gampe, J., Garagnani, P., de Geus, E. J., Harrow, J., van Heemst, D., Heijmans, B. T., Heinsen, F. A., Hottenga, J. J., Hofman, A., Jeune, B., Jonsson, P. V., Lathrop, M., Lechner, D., Martin-Ruiz, C., McNerlan, S. E., Mihailov, E., Montesanto, A., Mooijaart, S. P., Murphy, A., Nohr, E. A., Paternoster, L., Postmus, I., Rivadeneira, F., Ross, O. A., Salvioli, S., Sattar, N., Schreiber, S., Stefansson, H., Stott, D. J., Tiemeier, H., Uitterlinden, A. G., Westendorp, R. G., Willemsen, G., Samani, N. J., Galan, P., Sorensen, T. I., Boomsma, D. I., Jukema, J. W., Rea, I. M., Passarino, G., de Craen, A. J., 
Christensen, K., Nebel, A., Stefansson, K., Metspalu, A., Magnusson, P., Blanche, H., Christiansen, L., Kirkwood, T. B., van Duijn, C. M., Franceschi, C., HouwingDuistermaat, J. J., \& Slagboom, P. E. (2014, Aug 15). Genome-wide association metaanalysis of human longevity identifies a novel locus conferring survival beyond 90 years of age. Hum Mol Genet, 23(16), 4420-4432. https://doi.org/10.1093/hmg/ddu139

Deelen, J., Evans, D. S., Arking, D. E., Tesi, N., Nygaard, M., Liu, X., Wojczynski, M. K., Biggs, M. L., van der Spek, A., Atzmon, G., Ware, E. B., Sarnowski, C., Smith, A. V., Seppala, I., Cordell, H. J., Dose, J., Amin, N., Arnold, A. M., Ayers, K. L., Barzilai, N., Becker, E. J., Beekman, M., Blanche, H., Christensen, K., Christiansen, L., Collerton, J. C., Cubaynes, S., Cummings, S. R., Davies, K., Debrabant, B., Deleuze, J. F., Duncan, R., Faul, J. D., Franceschi, C., Galan, P., Gudnason, V., Harris, T. B., Huisman, M., Hurme, M. A., Jagger, C., Jansen, I., Jylha, M., Kahonen, M., Karasik, D., Kardia, S. L. R., Kingston, A., Kirkwood, T. B. L., Launer, L. J., Lehtimaki, T., Lieb, W., Lyytikainen, L. P., Martin-Ruiz, C., Min, J., Nebel, A., Newman, A. B., Nie, C., Nohr, E. A., Orwoll, E. S., Perls, T. T., Province, M. A., Psaty, B. M., Raitakari, O. T., Reinders, M. J. T., Robine, J. M., Rotter, J. I., Sebastiani, P., Smith, J., Sorensen, T. I. A., Taylor, K. D., Uitterlinden, A. G., van der Flier, W., van der Lee, S. J., van Duijn, C. M., van Heemst, D., Vaupel, J. W., Weir, D., Ye, K., Zeng, Y., Zheng, W., Holstege, H., Kiel, D. P., Lunetta, K. L., Slagboom, P. E., \& Murabito, J. M. (2019, Aug 14). A meta-analysis of genome-wide association studies identifies multiple longevity genes. Nat Commun, 10(1), 3669. https://doi.org/10.1038/s41467-019-11558-2

Delaunay, A., Bromberg, K. D., Hayashi, Y., Mirabella, M., Burch, D., Kirkwood, B., Serra, C., Malicdan, M. C., Mizisin, A. P., Morosetti, R., Broccolini, A., Guo, L. T., Jones, S. N., Lira, S. A., Puri, P. L., Shelton, G. D., \& Ronai, Z. (2008, Feb 13). The ER-bound RING finger protein 5 (RNF5/RMA1) causes degenerative myopathy in transgenic mice and is deregulated in inclusion body myositis. PLoS One, 3(2), e1609. https://doi.org/10.1371/journal.pone.0001609

Engberg, H., Oksuzyan, A., Jeune, B., Vaupel, J. W., \& Christensen, K. (2009, Jun). Centenarians--a useful model for healthy aging? A 29-year follow-up of hospitalizations among 40,000 Danes born in 1905. Aging Cell, 8(3), 270-276. https://doi.org/10.1111/j.1474-9726.2009.00474.x

Falvella, F. S., Galvan, A., Colombo, F., Frullanti, E., Pastorino, U., \& Dragani, T. A. (2010, Sep 8). Promoter polymorphisms and transcript levels of nicotinic receptor CHRNA5. J Natl Cancer Inst, 102(17), 1366-1370. https://doi.org/10.1093/jnci/djq264

Flachsbart, F., Caliebe, A., Kleindorp, R., Blanche, H., von Eller-Eberstein, H., Nikolaus, S., Schreiber, S., \& Nebel, A. (2009, Feb 24). Association of FOXO3A variation with human longevity confirmed in German centenarians. Proc Natl Acad Sci U S A, 106(8), 27002705. https://doi.org/10.1073/pnas.0809594106

Flachsbart, F., Dose, J., Gentschew, L., Geismann, C., Caliebe, A., Knecht, C., Nygaard, M., Badarinarayan, N., ElSharawy, A., May, S., Luzius, A., Torres, G. G., Jentzsch, M., 
Forster, M., Hasler, R., Pallauf, K., Lieb, W., Derbois, C., Galan, P., Drichel, D., Arlt, A., Till, A., Krause-Kyora, B., Rimbach, G., Blanche, H., Deleuze, J. F., Christiansen, L., Christensen, K., Nothnagel, M., Rosenstiel, P., Schreiber, S., Franke, A., Sebens, S., \& Nebel, A. (2017, Dec 12). Identification and characterization of two functional variants in the human longevity gene FOXO3. Nat Commun, 8(1), 2063. https://doi.org/10.1038/s41467-017-02183-y

Fortney, K., Dobriban, E., Garagnani, P., Pirazzini, C., Monti, D., Mari, D., Atzmon, G., Barzilai, N., Franceschi, C., Owen, A. B., \& Kim, S. K. (2015, Dec). Genome-Wide Scan Informed by Age-Related Disease Identifies Loci for Exceptional Human Longevity. PLoS Genet, 11(12), e1005728. https://doi.org/10.1371/journal.pgen.1005728

Fritsche, L. G., Chen, W., Schu, M., Yaspan, B. L., Yu, Y., Thorleifsson, G., Zack, D. J., Arakawa, S., Cipriani, V., Ripke, S., Igo, R. P., Jr., Buitendijk, G. H., Sim, X., Weeks, D. E., Guymer, R. H., Merriam, J. E., Francis, P. J., Hannum, G., Agarwal, A., Armbrecht, A. M., Audo, I., Aung, T., Barile, G. R., Benchaboune, M., Bird, A. C., Bishop, P. N., Branham, K. E., Brooks, M., Brucker, A. J., Cade, W. H., Cain, M. S., Campochiaro, P. A., Chan, C. C., Cheng, C. Y., Chew, E. Y., Chin, K. A., Chowers, I., Clayton, D. G., Cojocaru, R., Conley, Y. P., Cornes, B. K., Daly, M. J., Dhillon, B., Edwards, A. O., Evangelou, E., Fagerness, J., Ferreyra, H. A., Friedman, J. S., Geirsdottir, A., George, R. J., Gieger, C., Gupta, N., Hagstrom, S. A., Harding, S. P., Haritoglou, C., Heckenlively, J. R., Holz, F. G., Hughes, G., Ioannidis, J. P., Ishibashi, T., Joseph, P., Jun, G., Kamatani, Y., Katsanis, N., C, N. K., Khan, J. C., Kim, I. K., Kiyohara, Y., Klein, B. E., Klein, R., Kovach, J. L., Kozak, I., Lee, C. J., Lee, K. E., Lichtner, P., Lotery, A. J., Meitinger, T., Mitchell, P., Mohand-Said, S., Moore, A. T., Morgan, D. J., Morrison, M. A., Myers, C. E., Naj, A. C., Nakamura, Y., Okada, Y., Orlin, A., Ortube, M. C., Othman, M. I., Pappas, C., Park, K. H., Pauer, G. J., Peachey, N. S., Poch, O., Priya, R. R., Reynolds, R., Richardson, A. J., Ripp, R., Rudolph, G., Ryu, E., Sahel, J. A., Schaumberg, D. A., Scholl, H. P., Schwartz, S. G., Scott, W. K., Shahid, H., Sigurdsson, H., Silvestri, G., Sivakumaran, T. A., Smith, R. T., Sobrin, L., Souied, E. H., Stambolian, D. E., Stefansson, H., Sturgill-Short, G. M., Takahashi, A., Tosakulwong, N., Truitt, B. J., Tsironi, E. E., Uitterlinden, A. G., van Duijn, C. M., Vijaya, L., Vingerling, J. R., Vithana, E. N., Webster, A. R., Wichmann, H. E., Winkler, T. W., Wong, T. Y., Wright, A. F., Zelenika, D., Zhang, M., Zhao, L., Zhang, K., Klein, M. L., Hageman, G. S., Lathrop, G. M., Stefansson, K., Allikmets, R., Baird, P. N., Gorin, M. B., Wang, J. J., Klaver, C. C., Seddon, J. M., Pericak-Vance, M. A., Iyengar, S. K., Yates, J. R., Swaroop, A., Weber, B. H., Kubo, M., Deangelis, M. M., Leveillard, T., Thorsteinsdottir, U., Haines, J. L., Farrer, L. A., Heid, I. M., Abecasis, G. R., \& Consortium, A. M. D. G. (2013, Apr). Seven new loci associated with age-related macular degeneration. Nat Genet, 45(4), 433-439, 439e431-432. https://doi.org/10.1038/ng.2578

Gallagher, C. S., Makinen, N., Harris, H. R., Rahmioglu, N., Uimari, O., Cook, J. P., Shigesi, N., Ferreira, T., Velez-Edwards, D. R., Edwards, T. L., Mortlock, S., Ruhioglu, Z., Day, F., Becker, C. M., Karhunen, V., Martikainen, H., Jarvelin, M. R., Cantor, R. M., Ridker, P. M., Terry, K. L., Buring, J. E., Gordon, S. D., Medland, S. E., Montgomery, G. W., Nyholt, D. R., Hinds, D. A., Tung, J. Y., andMe Research, T., Perry, J. R. B., Lind, P. A., 

T., \& Morton, C. C. (2019, Oct 24). Genome-wide association and epidemiological analyses reveal common genetic origins between uterine leiomyomata and endometriosis. Nat Commun, 10(1), 4857. https://doi.org/10.1038/s41467-019-12536-4

Giambartolomei, C., Vukcevic, D., Schadt, E. E., Franke, L., Hingorani, A. D., Wallace, C., \& Plagnol, V. (2014, May). Bayesian test for colocalisation between pairs of genetic Chu, A. Y., Mahajan, A., Hadley, D., Xue, L., Workalemahu, T., Heard-Costa, N. L., den Hoed, M., Ahluwalia, T. S., Qi, Q., Ngwa, J. S., Renstrom, F., Quaye, L., Eicher, J. D., Hayes, J. E., Cornelis, M., Kutalik, Z., Lim, E., Luan, J., Huffman, J. E., Zhang, W., Zhao, W., Griffin, P. J., Haller, T., Ahmad, S., Marques-Vidal, P. M., Bien, S., Yengo, L., Teumer, A., Smith, A. V., Kumari, M., Harder, M. N., Justesen, J. M., Kleber, M. E., Hollensted, M., Lohman, K., Rivera, N. V., Whitfield, J. B., Zhao, J. H., Stringham, H. M., Lyytikainen, L. P., Huppertz, C., Willemsen, G., Peyrot, W. J., Wu, Y., Kristiansson, K., Demirkan, A., Fornage, M., Hassinen, M., Bielak, L. F., Cadby, G., Tanaka, T., Magi, R., van der Most, P. J., Jackson, A. U., Bragg-Gresham, J. L., Vitart, V., Marten, J., Navarro, P., Bellis, C., Pasko, D., Johansson, A., Snitker, S., Cheng, Y. C., Eriksson, J., Lim, U., Aadahl, M., Adair, L. S., Amin, N., Balkau, B., Auvinen, J., Beilby, J., Bergman, R. N., Bergmann, S., Bertoni, A. G., Blangero, J., Bonnefond, A., Bonnycastle, L. L., Borja, J. B., Brage, S., Busonero, F., Buyske, S., Campbell, H., Chines, P. S., Collins, F. S., Corre, T., Smith, G. D., Delgado, G. E., Dueker, N., Dorr, M., Ebeling, T., Eiriksdottir, G., Esko, T., Faul, J. D., Fu, M., Faerch, K., Gieger, C., Glaser, S., Gong, J., GordonLarsen, P., Grallert, H., Grammer, T. B., Grarup, N., van Grootheest, G., Harald, K., Hastie, N. D., Havulinna, A. S., Hernandez, D., Hindorff, L., Hocking, L. J., Holmens, O. L., Holzapfel, C., Hottenga, J. J., Huang, J., Huang, T., Hui, J., Huth, C., Hutri-Kahonen, N., James, A. L., Jansson, J. O., Jhun, M. A., Juonala, M., Kinnunen, L., Koistinen, H. A., Kolcic, I., Komulainen, P., Kuusisto, J., Kvaloy, K., Kahonen, M., Lakka, T. A., Launer, L. J., Lehne, B., Lindgren, C. M., Lorentzon, M., Luben, R., Marre, M., Milaneschi, Y., Monda, K. L., Montgomery, G. W., De Moor, M. H. M., Mulas, A., Muller-Nurasyid, M., Musk, A. W., Mannikko, R., Mannisto, S., Narisu, N., Nauck, M., Nettleton, J. A., Nolte, I. M., Oldehinkel, A. J., Olden, M., Ong, K. K., Padmanabhan, S., Paternoster, L., Perez, J., Perola, M., Peters, A., Peters, U., Peyser, P. A., Prokopenko, I., Puolijoki, H., Raitakari, O. T., Rankinen, T., Rasmussen-Torvik, L. J., Rawal, R., Ridker, P. M., Rose, L. M., Rudan, I., Sarti, C., Sarzynski, M. A., Savonen, K., Scott, W. R., Sanna, S., Shuldiner, A. R., Sidney, S., Silbernagel, G., Smith, B. H., Smith, J. A., Snieder, H., Stancakova, A., Sternfeld, B., Swift, A. J., Tammelin, T., Tan, S. T., Thorand, B., Thuillier, D., Vandenput, L., Vestergaard, H., van Vliet-Ostaptchouk, J. V., Vohl, M. C., Volker, U., Waeber, G., Walker, M., Wild, S., Wong, A., Wright, A. F., Zillikens, M. C., Zubair, N., Haiman, C. A., Lemarchand, L., Gyllensten, U., Ohlsson, C., Hofman, A., Rivadeneira, F., Uitterlinden, A. G., Perusse, L., Wilson, J. F., Hayward, C., Polasek, O., Cucca, F., Hveem, K., Hartman, C. A., Tonjes, A., Bandinelli, S., Palmer, L. J., Kardia, S. L. R., Rauramaa, R., Sorensen, T. I. A., Tuomilehto, J., Salomaa, V., Penninx, B., de 

Harris, T. B., Gudnason, V., Volzke, H., Qi, L., Jarvelin, M. R., Chambers, J. C., Kooner, J. S., Froguel, P., Kooperberg, C., Vollenweider, P., Hallmans, G., Hansen, T., Pedersen, O., Metspalu, A., Wareham, N. J., Langenberg, C., Weir, D. R., Porteous, D. J., Boerwinkle, E., Chasman, D. I., Consortium, C., Consortium, E. P.-I., Consortium, P., Abecasis, G. R., Barroso, I., McCarthy, M. I., Frayling, T. M., O'Connell, J. R., van Duijn, C. M., Boehnke, M., Heid, I. M., Mohlke, K. L., Strachan, D. P., Fox, C. S., Liu, C. T., Hirschhorn, J. N., Klein, R. J., Johnson, A. D., Borecki, I. B., Franks, P. W., North, K. E., Cupples, L. A., Loos, R. J. F., \& Kilpelainen, T. O. (2017, Apr). Genome-wide physical activity interactions in adiposity - A meta-analysis of 200,452 adults. PLoS Genet, 13(4), e1006528. https://doi.org/10.1371/journal.pgen.1006528

Hao, K., Bosse, Y., Nickle, D. C., Pare, P. D., Postma, D. S., Laviolette, M., Sandford, A., Hackett, T. L., Daley, D., Hogg, J. C., Elliott, W. M., Couture, C., Lamontagne, M., Brandsma, C. A., van den Berge, M., Koppelman, G., Reicin, A. S., Nicholson, D. W., Malkov, V., Derry, J. M., Suver, C., Tsou, J. A., Kulkarni, A., Zhang, C., Vessey, R., Opiteck, G. J., Curtis, S. P., Timens, W., \& Sin, D. D. (2012). Lung eQTLs to help reveal the molecular underpinnings of asthma. PLoS Genet, 8(11), e1003029. https://doi.org/10.1371/journal.pgen.1003029

Herskind, A. M., McGue, M., Holm, N. V., Sorensen, T. I., Harvald, B., \& Vaupel, J. W. (1996, Mar). The heritability of human longevity: a population-based study of 2872 Danish twin pairs born 1870-1900. Hum Genet, 97(3), 319-323. https://doi.org/10.1007/BF02185763

Huang da, W., Sherman, B. T., \& Lempicki, R. A. (2009, Jan). Bioinformatics enrichment tools: paths toward the comprehensive functional analysis of large gene lists. Nucleic Acids Res, 37(1), 1-13. https://doi.org/10.1093/nar/gkn923

Jansen, I. E., Savage, J. E., Watanabe, K., Bryois, J., Williams, D. M., Steinberg, S., Sealock, J., Karlsson, I. K., Hagg, S., Athanasiu, L., Voyle, N., Proitsi, P., Witoelar, A., Stringer, S., Aarsland, D., Almdahl, I. S., Andersen, F., Bergh, S., Bettella, F., Bjornsson, S., Braekhus, A., Brathen, G., de Leeuw, C., Desikan, R. S., Djurovic, S., Dumitrescu, L., Fladby, T., Hohman, T. J., Jonsson, P. V., Kiddle, S. J., Rongve, A., Saltvedt, I., Sando, S. B., Selbaek, G., Shoai, M., Skene, N. G., Snaedal, J., Stordal, E., Ulstein, I. D., Wang, Y., White, L. R., Hardy, J., Hjerling-Leffler, J., Sullivan, P. F., van der Flier, W. M., Dobson, R., Davis, L. K., Stefansson, H., Stefansson, K., Pedersen, N. L., Ripke, S., Andreassen, O. A., \& Posthuma, D. (2019, Mar). Genome-wide meta-analysis identifies new loci and functional pathways influencing Alzheimer's disease risk. Nat Genet, 51(3), 404-413. https://doi.org/10.1038/s41588-018-0311-9

Jasinska, A. J. (2020, May). Resources for functional genomic studies of health and development in nonhuman primates. Am $J$ Phys Anthropol, 171 Suppl 70, 174-194. https://doi.org/10.1002/ajpa.24051 
Jaul, E., \& Barron, J. (2017). Age-Related Diseases and Clinical and Public Health Implications for the 85 Years Old and Over Population. Front Public Health, 5, 335. https://doi.org/10.3389/fpubh.2017.00335

Joshi, P. K., Pirastu, N., Kentistou, K. A., Fischer, K., Hofer, E., Schraut, K. E., Clark, D. W., Nutile, T., Barnes, C. L. K., Timmers, P., Shen, X., Gandin, I., McDaid, A. F., Hansen, T. F., Gordon, S. D., Giulianini, F., Boutin, T. S., Abdellaoui, A., Zhao, W., Medina-Gomez, C., Bartz, T. M., Trompet, S., Lange, L. A., Raffield, L., van der Spek, A., Galesloot, T. E., Proitsi, P., Yanek, L. R., Bielak, L. F., Payton, A., Murgia, F., Concas, M. P., Biino, G., Tajuddin, S. M., Seppala, I., Amin, N., Boerwinkle, E., Borglum, A. D., Campbell, A., Demerath, E. W., Demuth, I., Faul, J. D., Ford, I., Gialluisi, A., Gogele, M., Graff, M., Hingorani, A., Hottenga, J. J., Hougaard, D. M., Hurme, M. A., Ikram, M. A., Jylha, M., Kuh, D., Ligthart, L., Lill, C. M., Lindenberger, U., Lumley, T., Magi, R., Marques-Vidal, P., Medland, S. E., Milani, L., Nagy, R., Ollier, W. E. R., Peyser, P. A., Pramstaller, P. P., Ridker, P. M., Rivadeneira, F., Ruggiero, D., Saba, Y., Schmidt, R., Schmidt, H., Slagboom, P. E., Smith, B. H., Smith, J. A., Sotoodehnia, N., Steinhagen-Thiessen, E., van Rooij, F. J. A., Verbeek, A. L., Vermeulen, S. H., Vollenweider, P., Wang, Y., Werge, T., Whitfield, J. B., Zonderman, A. B., Lehtimaki, T., Evans, M. K., Pirastu, M., Fuchsberger, C., Bertram, L., Pendleton, N., Kardia, S. L. R., Ciullo, M., Becker, D. M., Wong, A., Psaty, B. M., van Duijn, C. M., Wilson, J. G., Jukema, J. W., Kiemeney, L., Uitterlinden, A. G., Franceschini, N., North, K. E., Weir, D. R., Metspalu, A., Boomsma, D. I., Hayward, C., Chasman, D., Martin, N. G., Sattar, N., Campbell, H., Esko, T., Kutalik, Z., \& Wilson, J. F. (2017, Oct 13). Genome-wide meta-analysis associates HLADQA1/DRB1 and LPA and lifestyle factors with human longevity. Nat Commun, 8(1), 910. https://doi.org/10.1038/s41467-017-00934-5

Jun, G. R., Chung, J., Mez, J., Barber, R., Beecham, G. W., Bennett, D. A., Buxbaum, J. D., Byrd, G. S., Carrasquillo, M. M., Crane, P. K., Cruchaga, C., De Jager, P., Ertekin-Taner, N., Evans, D., Fallin, M. D., Foroud, T. M., Friedland, R. P., Goate, A. M., GraffRadford, N. R., Hendrie, H., Hall, K. S., Hamilton-Nelson, K. L., Inzelberg, R., Kamboh, M. I., Kauwe, J. S. K., Kukull, W. A., Kunkle, B. W., Kuwano, R., Larson, E. B., Logue, M. W., Manly, J. J., Martin, E. R., Montine, T. J., Mukherjee, S., Naj, A., Reiman, E. M., Reitz, C., Sherva, R., St George-Hyslop, P. H., Thornton, T., Younkin, S. G., Vardarajan, B. N., Wang, L. S., Wendlund, J. R., Winslow, A. R., Alzheimer's Disease Genetics, C., Haines, J., Mayeux, R., Pericak-Vance, M. A., Schellenberg, G., Lunetta, K. L., \& Farrer, L. A. (2017, Jul). Transethnic genome-wide scan identifies novel Alzheimer's disease loci. Alzheimers Dement, 13(7), 727-738. https://doi.org/10.1016/j.jalz.2016.12.012

Koopmann, T. T., Adriaens, M. E., Moerland, P. D., Marsman, R. F., Westerveld, M. L., Lal, S., Zhang, T., Simmons, C. Q., Baczko, I., dos Remedios, C., Bishopric, N. H., Varro, A., George, A. L., Jr., Lodder, E. M., \& Bezzina, C. R. (2014). Genome-wide identification of expression quantitative trait loci (eQTLs) in human heart. PLoS One, 9(5), e97380. https://doi.org/10.1371/journal.pone.0097380

Krautkramer, K. A., Linnemann, A. K., Fontaine, D. A., Whillock, A. L., Harris, T. W., Schleis, G. J., Truchan, N. A., Marty-Santos, L., Lavine, J. A., Cleaver, O., Kimple, M. E., \& 
Davis, D. B. (2013, Sep 1). Tcf19 is a novel islet factor necessary for proliferation and survival in the INS-1 beta-cell line. Am J Physiol Endocrinol Metab, 305(5), E600-610. https://doi.org/10.1152/ajpendo.00147.2013

Kuhns, D. B., Hsu, A. P., Sun, D., Lau, K., Fink, D., Griffith, P., Huang, D. W., Priel, D. A. L., Mendez, L., Kreuzburg, S., Zerbe, C. S., De Ravin, S. S., Malech, H. L., Holland, S. M., Wu, X., \& Gallin, J. I. (2019, Jan 22). NCF1 (p47(phox))-deficient chronic granulomatous disease: comprehensive genetic and flow cytometric analysis. Blood Adv, 3(2), 136-147. https://doi.org/10.1182/bloodadvances.2018023184

Li, Y., Wang, W. J., Cao, H., Lu, J., Wu, C., Hu, F. Y., Guo, J., Zhao, L., Yang, F., Zhang, Y. X., Li, W., Zheng, G. Y., Cui, H., Chen, X., Zhu, Z., He, H., Dong, B., Mo, X., Zeng, Y., \& Tian, X. L. (2009, Dec 15). Genetic association of FOXO1A and FOXO3A with longevity trait in Han Chinese populations. Hum Mol Genet, 18(24), 4897-4904. https://doi.org/10.1093/hmg/ddp459

Mahajan, A., Taliun, D., Thurner, M., Robertson, N. R., Torres, J. M., Rayner, N. W., Payne, A. J., Steinthorsdottir, V., Scott, R. A., Grarup, N., Cook, J. P., Schmidt, E. M., Wuttke, M., Sarnowski, C., Magi, R., Nano, J., Gieger, C., Trompet, S., Lecoeur, C., Preuss, M. H., Prins, B. P., Guo, X., Bielak, L. F., Below, J. E., Bowden, D. W., Chambers, J. C., Kim, Y. J., Ng, M. C. Y., Petty, L. E., Sim, X., Zhang, W., Bennett, A. J., Bork-Jensen, J., Brummett, C. M., Canouil, M., Ec Kardt, K. U., Fischer, K., Kardia, S. L. R., Kronenberg, F., Lall, K., Liu, C. T., Locke, A. E., Luan, J., Ntalla, I., Nylander, V., Schonherr, S., Schurmann, C., Yengo, L., Bottinger, E. P., Brandslund, I., Christensen, C., Dedoussis, G., Florez, J. C., Ford, I., Franco, O. H., Frayling, T. M., Giedraitis, V., Hackinger, S., Hattersley, A. T., Herder, C., Ikram, M. A., Ingelsson, M., Jorgensen, M. E., Jorgensen, T., Kriebel, J., Kuusisto, J., Ligthart, S., Lindgren, C. M., Linneberg, A., Lyssenko, V., Mamakou, V., Meitinger, T., Mohlke, K. L., Morris, A. D., Nadkarni, G., Pankow, J. S., Peters, A., Sattar, N., Stancakova, A., Strauch, K., Taylor, K. D., Thorand, B., Thorleifsson, G., Thorsteinsdottir, U., Tuomilehto, J., Witte, D. R., Dupuis, J., Peyser, P. A., Zeggini, E., Loos, R. J. F., Froguel, P., Ingelsson, E., Lind, L., Groop, L., Laakso, M., Collins, F. S., Jukema, J. W., Palmer, C. N. A., Grallert, H., Metspalu, A., Dehghan, A., Kottgen, A., Abecasis, G. R., Meigs, J. B., Rotter, J. I., Marchini, J., Pedersen, O., Hansen, T., Langenberg, C., Wareham, N. J., Stefansson, K., Gloyn, A. L., Morris, A. P., Boehnke, M., \& McCarthy, M. I. (2018, Nov). Fine-mapping type 2 diabetes loci to single-variant resolution using high-density imputation and islet-specific epigenome maps. Nat Genet, 50(11), 1505-1513. https://doi.org/10.1038/s41588-018-0241-6

Mahajan, A., Wessel, J., Willems, S. M., Zhao, W., Robertson, N. R., Chu, A. Y., Gan, W., Kitajima, H., Taliun, D., Rayner, N. W., Guo, X., Lu, Y., Li, M., Jensen, R. A., Hu, Y., Huo, S., Lohman, K. K., Zhang, W., Cook, J. P., Prins, B. P., Flannick, J., Grarup, N., Trubetskoy, V. V., Kravic, J., Kim, Y. J., Rybin, D. V., Yaghootkar, H., Muller-Nurasyid, M., Meidtner, K., Li-Gao, R., Varga, T. V., Marten, J., Li, J., Smith, A. V., An, P., Ligthart, S., Gustafsson, S., Malerba, G., Demirkan, A., Tajes, J. F., Steinthorsdottir, V., Wuttke, M., Lecoeur, C., Preuss, M., Bielak, L. F., Graff, M., Highland, H. M., Justice, A. E., Liu, D. J., Marouli, E., Peloso, G. M., Warren, H. R., Exome, B. P. C., Consortium, 

Bertoni, A. G., Bombieri, C., Bork-Jensen, J., Brandslund, I., Brody, J. A., Burtt, N. P., Canouil, M., Chen, Y. I., Cho, Y. S., Christensen, C., Eastwood, S. V., Eckardt, K. U., Fischer, K., Gambaro, G., Giedraitis, V., Grove, M. L., de Haan, H. G., Hackinger, S., Hai, Y., Han, S., Tybjaerg-Hansen, A., Hivert, M. F., Isomaa, B., Jager, S., Jorgensen, M. E., Jorgensen, T., Karajamaki, A., Kim, B. J., Kim, S. S., Koistinen, H. A., Kovacs, P., Kriebel, J., Kronenberg, F., Lall, K., Lange, L. A., Lee, J. J., Lehne, B., Li, H., Lin, K. H., Linneberg, A., Liu, C. T., Liu, J., Loh, M., Magi, R., Mamakou, V., McKean-Cowdin, R., Nadkarni, G., Neville, M., Nielsen, S. F., Ntalla, I., Peyser, P. A., Rathmann, W., Rice, K., Rich, S. S., Rode, L., Rolandsson, O., Schonherr, S., Selvin, E., Small, K. S., Stancakova, A., Surendran, P., Taylor, K. D., Teslovich, T. M., Thorand, B., Thorleifsson, G., Tin, A., Tonjes, A., Varbo, A., Witte, D. R., Wood, A. R., Yajnik, P., Yao, J., Yengo, L., Young, R., Amouyel, P., Boeing, H., Boerwinkle, E., Bottinger, E. P., Chowdhury, R., Collins, F. S., Dedoussis, G., Dehghan, A., Deloukas, P., Ferrario, M. M., Ferrieres, J., Florez, J. C., Frossard, P., Gudnason, V., Harris, T. B., Heckbert, S. R., Howson, J. M. M., Ingelsson, M., Kathiresan, S., Kee, F., Kuusisto, J., Langenberg, C., Launer, L. J., Lindgren, C. M., Mannisto, S., Meitinger, T., Melander, O., Mohlke, K. L., Moitry, M., Morris, A. D., Murray, A. D., de Mutsert, R., Orho-Melander, M., Owen, K. R., Perola, M., Peters, A., Province, M. A., Rasheed, A., Ridker, P. M., Rivadineira, F., Rosendaal, F. R., Rosengren, A. H., Salomaa, V., Sheu, W. H., Sladek, R., Smith, B. H., Strauch, K., Uitterlinden, A. G., Varma, R., Willer, C. J., Bluher, M., Butterworth, A. S., Chambers, J. C., Chasman, D. I., Danesh, J., van Duijn, C., Dupuis, J., Franco, O. H., Franks, P. W., Froguel, P., Grallert, H., Groop, L., Han, B. G., Hansen, T., Hattersley, A. T., Hayward, C., Ingelsson, E., Kardia, S. L. R., Karpe, F., Kooner, J. S., Kottgen, A., Kuulasmaa, K., Laakso, M., Lin, X., Lind, L., Liu, Y., Loos, R. J. F., Marchini, J., Metspalu, A., MookKanamori, D., Nordestgaard, B. G., Palmer, C. N. A., Pankow, J. S., Pedersen, O., Psaty, B. M., Rauramaa, R., Sattar, N., Schulze, M. B., Soranzo, N., Spector, T. D., Stefansson, K., Stumvoll, M., Thorsteinsdottir, U., Tuomi, T., Tuomilehto, J., Wareham, N. J., Wilson, J. G., Zeggini, E., Scott, R. A., Barroso, I., Frayling, T. M., Goodarzi, M. O., Meigs, J. B., Boehnke, M., Saleheen, D., Morris, A. P., Rotter, J. I., \& McCarthy, M. I. (2018, Apr). Refining the accuracy of validated target identification through coding variant fine-mapping in type 2 diabetes. Nat Genet, 50(4), 559-571. https://doi.org/10.1038/s41588-018-0084-1 L., Giese, A. K., van der Laan, S. W., Gretarsdottir, S., Anderson, C. D., Chong, M., Adams, H. H. H., Ago, T., Almgren, P., Amouyel, P., Ay, H., Bartz, T. M., Benavente, O. R., Bevan, S., Boncoraglio, G. B., Brown, R. D., Jr., Butterworth, A. S., Carrera, C., Carty, C. L., Chasman, D. I., Chen, W. M., Cole, J. W., Correa, A., Cotlarciuc, I., Cruchaga, C., Danesh, J., de Bakker, P. I. W., DeStefano, A. L., den Hoed, M., Duan, Q., Engelter, S. T., Falcone, G. J., Gottesman, R. F., Grewal, R. P., Gudnason, V., Gustafsson, S., Haessler, J., Harris, T. B., Hassan, A., Havulinna, A. S., Heckbert, S. R., Holliday, E. G., Howard, G., Hsu, F. C., Hyacinth, H. I., Ikram, M. A., Ingelsson, E., Irvin, M. R., Jian, X., Jimenez-Conde, J., Johnson, J. A., Jukema, J. W., Kanai, M., Keene, K. L., Kissela, B. M., Kleindorfer, D. O., Kooperberg, C., Kubo, M., Lange, L. A., Langefeld, C. D., Langenberg, C., Launer, L. J., Lee, J. M., Lemmens, R., Leys, D., 
882

883

884

885

886

887

888

889

890

891

892

893

894

895

896

897

898

899

900

901

902

903

904

905

906

907

908

909

910

911

912

913

914

915

916

917

918

919

920

921

922

923

924

925

926

927

Lewis, C. M., Lin, W. Y., Lindgren, A. G., Lorentzen, E., Magnusson, P. K., Maguire, J., Manichaikul, A., McArdle, P. F., Meschia, J. F., Mitchell, B. D., Mosley, T. H., Nalls, M. A., Ninomiya, T., O'Donnell, M. J., Psaty, B. M., Pulit, S. L., Rannikmae, K., Reiner, A. P., Rexrode, K. M., Rice, K., Rich, S. S., Ridker, P. M., Rost, N. S., Rothwell, P. M., Rotter, J. I., Rundek, T., Sacco, R. L., Sakaue, S., Sale, M. M., Salomaa, V., Sapkota, B. R., Schmidt, R., Schmidt, C. O., Schminke, U., Sharma, P., Slowik, A., Sudlow, C. L. M., Tanislav, C., Tatlisumak, T., Taylor, K. D., Thijs, V. N. S., Thorleifsson, G., Thorsteinsdottir, U., Tiedt, S., Trompet, S., Tzourio, C., van Duijn, C. M., Walters, M., Wareham, N. J., Wassertheil-Smoller, S., Wilson, J. G., Wiggins, K. L., Yang, Q., Yusuf, S., Consortium, A. F., Cohorts for, H., Aging Research in Genomic Epidemiology, C., International Genomics of Blood Pressure, C., Consortium, I., Starnet, Bis, J. C., Pastinen, T., Ruusalepp, A., Schadt, E. E., Koplev, S., Bjorkegren, J. L. M., Codoni, V., Civelek, M., Smith, N. L., Tregouet, D. A., Christophersen, I. E., Roselli, C., Lubitz, S. A., Ellinor, P. T., Tai, E. S., Kooner, J. S., Kato, N., He, J., van der Harst, P., Elliott, P., Chambers, J. C., Takeuchi, F., Johnson, A. D., BioBank Japan Cooperative Hospital, G., Consortium, C., Consortium, E.-C., Consortium, E. P.-I., International Stroke Genetics, C., Consortium, M., Neurology Working Group of the, C. C., Network, N. S. G., Study, U. K. Y. L. D., Consortium, M., Sanghera, D. K., Melander, O., Jern, C., Strbian, D., Fernandez-Cadenas, I., Longstreth, W. T., Jr., Rolfs, A., Hata, J., Woo, D., Rosand, J., Pare, G., Hopewell, J. C., Saleheen, D., Stefansson, K., Worrall, B. B., Kittner, S. J., Seshadri, S., Fornage, M., Markus, H. S., Howson, J. M. M., Kamatani, Y., Debette, S., \& Dichgans, M. (2018, Apr). Multiancestry genome-wide association study of 520,000 subjects identifies 32 loci associated with stroke and stroke subtypes. Nat Genet, 50(4), 524-537. https://doi.org/10.1038/s41588-018-0058-3

McDaid, A. F., Joshi, P. K., Porcu, E., Komljenovic, A., Li, H., Sorrentino, V., Litovchenko, M., Bevers, R. P. J., Rueger, S., Reymond, A., Bochud, M., Deplancke, B., Williams, R. W., Robinson-Rechavi, M., Paccaud, F., Rousson, V., Auwerx, J., Wilson, J. F., \& Kutalik, Z. (2017, Jul 27). Bayesian association scan reveals loci associated with human lifespan and linked biomarkers. Nat Commun, 8, 15842. https://doi.org/10.1038/ncomms15842

Melzer, D., Pilling, L. C., \& Ferrucci, L. (2020, Feb). The genetics of human ageing. Nat Rev Genet, 21(2), 88-101. https://doi.org/10.1038/s41576-019-0183-6

Menon, A. G., Morreau, H., Tollenaar, R. A., Alphenaar, E., Van Puijenbroek, M., Putter, H., Janssen-Van Rhijn, C. M., Van De Velde, C. J., Fleuren, G. J., \& Kuppen, P. J. (2002, Dec). Down-regulation of HLA-A expression correlates with a better prognosis in colorectal cancer patients. Lab Invest, 82(12), 1725-1733. https://doi.org/10.1097/01.lab.0000043124.75633.ed

Michailidou, K., Lindstrom, S., Dennis, J., Beesley, J., Hui, S., Kar, S., Lemacon, A., Soucy, P., Glubb, D., Rostamianfar, A., Bolla, M. K., Wang, Q., Tyrer, J., Dicks, E., Lee, A., Wang, Z., Allen, J., Keeman, R., Eilber, U., French, J. D., Qing Chen, X., Fachal, L., McCue, K., McCart Reed, A. E., Ghoussaini, M., Carroll, J. S., Jiang, X., Finucane, H., Adams, M., Adank, M. A., Ahsan, H., Aittomaki, K., Anton-Culver, H., Antonenkova, N. N., Arndt, V., Aronson, K. J., Arun, B., Auer, P. L., Bacot, F., Barrdahl, M., Baynes, C., Beckmann, 
M. W., Behrens, S., Benitez, J., Bermisheva, M., Bernstein, L., Blomqvist, C., Bogdanova, N. V., Bojesen, S. E., Bonanni, B., Borresen-Dale, A. L., Brand, J. S., Brauch, H., Brennan, P., Brenner, H., Brinton, L., Broberg, P., Brock, I. W., Broeks, A., Brooks-Wilson, A., Brucker, S. Y., Bruning, T., Burwinkel, B., Butterbach, K., Cai, Q., Cai, H., Caldes, T., Canzian, F., Carracedo, A., Carter, B. D., Castelao, J. E., Chan, T. L., David Cheng, T. Y., Seng Chia, K., Choi, J. Y., Christiansen, H., Clarke, C. L., Collaborators, N., Collee, M., Conroy, D. M., Cordina-Duverger, E., Cornelissen, S., Cox, D. G., Cox, A., Cross, S. S., Cunningham, J. M., Czene, K., Daly, M. B., Devilee, P., Doheny, K. F., Dork, T., Dos-Santos-Silva, I., Dumont, M., Durcan, L., Dwek, M., Eccles, D. M., Ekici, A. B., Eliassen, A. H., Ellberg, C., Elvira, M., Engel, C., Eriksson, M., Fasching, P. A., Figueroa, J., Flesch-Janys, D., Fletcher, O., Flyger, H., Fritschi, L., Gaborieau, V., Gabrielson, M., Gago-Dominguez, M., Gao, Y. T., Gapstur, S. M., Garcia-Saenz, J. A., Gaudet, M. M., Georgoulias, V., Giles, G. G., Glendon, G., Goldberg, M. S., Goldgar, D. E., Gonzalez-Neira, A., Grenaker Alnaes, G. I., Grip, M., Gronwald, J., Grundy, A., Guenel, P., Haeberle, L., Hahnen, E., Haiman, C. A., Hakansson, N., Hamann, U., Hamel, N., Hankinson, S., Harrington, P., Hart, S. N., Hartikainen, J. M., Hartman, M., Hein, A., Heyworth, J., Hicks, B., Hillemanns, P., Ho, D. N., Hollestelle, A., Hooning, M. J., Hoover, R. N., Hopper, J. L., Hou, M. F., Hsiung, C. N., Huang, G., Humphreys, K., Ishiguro, J., Ito, H., Iwasaki, M., Iwata, H., Jakubowska, A., Janni, W., John, E. M., Johnson, N., Jones, K., Jones, M., JukkolaVuorinen, A., Kaaks, R., Kabisch, M., Kaczmarek, K., Kang, D., Kasuga, Y., Kerin, M. J., Khan, S., Khusnutdinova, E., Kiiski, J. I., Kim, S. W., Knight, J. A., Kosma, V. M., Kristensen, V. N., Kruger, U., Kwong, A., Lambrechts, D., Le Marchand, L., Lee, E., Lee, M. H., Lee, J. W., Neng Lee, C., Lejbkowicz, F., Li, J., Lilyquist, J., Lindblom, A., Lissowska, J., Lo, W. Y., Loibl, S., Long, J., Lophatananon, A., Lubinski, J., Luccarini, C., Lux, M. P., Ma, E. S. K., MacInnis, R. J., Maishman, T., Makalic, E., Malone, K. E., Kostovska, I. M., Mannermaa, A., Manoukian, S., Manson, J. E., Margolin, S., Mariapun, S., Martinez, M. E., Matsuo, K., Mavroudis, D., McKay, J., McLean, C., MeijersHeijboer, H., Meindl, A., Menendez, P., Menon, U., Meyer, J., Miao, H., Miller, N., Taib, N. A. M., Muir, K., Mulligan, A. M., Mulot, C., Neuhausen, S. L., Nevanlinna, H., Neven, P., Nielsen, S. F., Noh, D. Y., Nordestgaard, B. G., Norman, A., Olopade, O. I., Olson, J. E., Olsson, H., Olswold, C., Orr, N., Pankratz, V. S., Park, S. K., Park-Simon, T. W., Lloyd, R., Perez, J. I. A., Peterlongo, P., Peto, J., Phillips, K. A., Pinchev, M., PlaseskaKaranfilska, D., Prentice, R., Presneau, N., Prokofyeva, D., Pugh, E., Pylkas, K., Rack, B., Radice, P., Rahman, N., Rennert, G., Rennert, H. S., Rhenius, V., Romero, A., Romm, J., Ruddy, K. J., Rudiger, T., Rudolph, A., Ruebner, M., Rutgers, E. J. T., Saloustros, E., Sandler, D. P., Sangrajrang, S., Sawyer, E. J., Schmidt, D. F., Schmutzler, R. K., Schneeweiss, A., Schoemaker, M. J., Schumacher, F., Schurmann, P., Scott, R. J., Scott, C., Seal, S., Seynaeve, C., Shah, M., Sharma, P., Shen, C. Y., Sheng, G., Sherman, M. E., Shrubsole, M. J., Shu, X. O., Smeets, A., Sohn, C., Southey, M. C., Spinelli, J. J., Stegmaier, C., Stewart-Brown, S., Stone, J., Stram, D. O., Surowy, H., Swerdlow, A., Tamimi, R., Taylor, J. A., Tengstrom, M., Teo, S. H., Beth Terry, M., Tessier, D. C., Thanasitthichai, S., Thone, K., Tollenaar, R., Tomlinson, I., Tong, L., Torres, D., Truong, T., Tseng, C. C., Tsugane, S., Ulmer, H. U., Ursin, G., Untch, M., Vachon, C., van Asperen, C. J., Van Den Berg, D., van den Ouweland, A. M. W., van der Kolk, L., van der Luijt, R. B., Vincent, D., Vollenweider, J., Waisfisz, Q., Wang-Gohrke, S., Weinberg, 
C. R., Wendt, C., Whittemore, A. S., Wildiers, H., Willett, W., Winqvist, R., Wolk, A., Wu, A. H., Xia, L., Yamaji, T., Yang, X. R., Har Yip, C., Yoo, K. Y., Yu, J. C., Zheng, W., Zheng, Y., Zhu, B., Ziogas, A., Ziv, E., Investigators, A., ConFab, A. I., Lakhani, S. R., Antoniou, A. C., Droit, A., Andrulis, I. L., Amos, C. I., Couch, F. J., Pharoah, P. D. P., Chang-Claude, J., Hall, P., Hunter, D. J., Milne, R. L., Garcia-Closas, M., Schmidt, M. K., Chanock, S. J., Dunning, A. M., Edwards, S. L., Bader, G. D., Chenevix-Trench, G., Simard, J., Kraft, P., \& Easton, D. F. (2017, Nov 2). Association analysis identifies 65 new breast cancer risk loci. Nature, 551(7678), 92-94. https://doi.org/10.1038/nature24284

Mitchell, B. D., Hsueh, W. C., King, T. M., Pollin, T. I., Sorkin, J., Agarwala, R., Schaffer, A. A., $\&$ Shuldiner, A. R. (2001, Sep 1). Heritability of life span in the Old Order Amish. Am J Med Genet, 102(4), 346-352. https://doi.org/10.1002/ajmg.1483

Miyoshi, N., Fujino, S., Ohue, M., Yasui, M., Takahashi, Y., Sugimura, K., Tomokuni, A., Akita, H., Kobayashi, S., Takahashi, H., Omori, T., Miyata, H., \& Yano, M. (2018, Jul). The POU5F1 gene expression in colorectal cancer: a novel prognostic marker. Surg Today, 48(7), 709-715. https://doi.org/10.1007/s00595-018-1644-9

Moreno-Grau, S., de Rojas, I., Hernandez, I., Quintela, I., Montrreal, L., Alegret, M., HernandezOlasagarre, B., Madrid, L., Gonzalez-Perez, A., Maronas, O., Rosende-Roca, M., Mauleon, A., Vargas, L., Lafuente, A., Abdelnour, C., Rodriguez-Gomez, O., Gil, S., Santos-Santos, M. A., Espinosa, A., Ortega, G., Sanabria, A., Perez-Cordon, A., Canabate, P., Moreno, M., Preckler, S., Ruiz, S., Aguilera, N., Pineda, J. A., Macias, J., Alarcon-Martin, E., Sotolongo-Grau, O., consortium, G. A., consortium, D., Alzheimer's Disease Neuroimaging, I., Marquie, M., Monte-Rubio, G., Valero, S., Benaque, A., Clarimon, J., Bullido, M. J., Garcia-Ribas, G., Pastor, P., Sanchez-Juan, P., Alvarez, V., Pinol-Ripoll, G., Garcia-Alberca, J. M., Royo, J. L., Franco, E., Mir, P., Calero, M., Medina, M., Rabano, A., Avila, J., Antunez, C., Real, L. M., Orellana, A., Carracedo, A., Saez, M. E., Tarraga, L., Boada, M., \& Ruiz, A. (2019, Oct). Genome-wide association analysis of dementia and its clinical endophenotypes reveal novel loci associated with Alzheimer's disease and three causality networks: The GR @ACE project. Alzheimers Dement, 15(10), 1333-1347. https://doi.org/10.1016/j.jalz.2019.06.4950

Morris, J. A., Kemp, J. P., Youlten, S. E., Laurent, L., Logan, J. G., Chai, R. C., Vulpescu, N. A., Forgetta, V., Kleinman, A., Mohanty, S. T., Sergio, C. M., Quinn, J., Nguyen-Yamamoto, L., Luco, A. L., Vijay, J., Simon, M. M., Pramatarova, A., Medina-Gomez, C., Trajanoska, K., Ghirardello, E. J., Butterfield, N. C., Curry, K. F., Leitch, V. D., Sparkes, P. C., Adoum, A. T., Mannan, N. S., Komla-Ebri, D. S. K., Pollard, A. S., Dewhurst, H. F., Hassall, T. A. D., Beltejar, M. G., andMe Research, T., Adams, D. J., Vaillancourt, S. M., Kaptoge, S., Baldock, P., Cooper, C., Reeve, J., Ntzani, E. E., Evangelou, E., Ohlsson, C., Karasik, D., Rivadeneira, F., Kiel, D. P., Tobias, J. H., Gregson, C. L., Harvey, N. C., Grundberg, E., Goltzman, D., Adams, D. J., Lelliott, C. J., Hinds, D. A., Ackert-Bicknell, C. L., Hsu, Y. H., Maurano, M. T., Croucher, P. I., Williams, G. R., Bassett, J. H. D., Evans, D. M., \& Richards, J. B. (2019, Feb). An atlas of genetic 
influences on osteoporosis in humans and mice. Nat Genet, 51(2), 258-266. https://doi.org/10.1038/s41588-018-0302-X

Ng, B., White, C. C., Klein, H. U., Sieberts, S. K., McCabe, C., Patrick, E., Xu, J., Yu, L., Gaiteri, C., Bennett, D. A., Mostafavi, S., \& De Jager, P. L. (2017, Oct). An xQTL map integrates the genetic architecture of the human brain's transcriptome and epigenome. Nat Neurosci, 20(10), 1418-1426. https://doi.org/10.1038/nn.4632

Nica, A. C., Parts, L., Glass, D., Nisbet, J., Barrett, A., Sekowska, M., Travers, M., Potter, S., Grundberg, E., Small, K., Hedman, A. K., Bataille, V., Tzenova Bell, J., Surdulescu, G., Dimas, A. S., Ingle, C., Nestle, F. O., di Meglio, P., Min, J. L., Wilk, A., Hammond, C. J., Hassanali, N., Yang, T. P., Montgomery, S. B., O'Rahilly, S., Lindgren, C. M., Zondervan, K. T., Soranzo, N., Barroso, I., Durbin, R., Ahmadi, K., Deloukas, P., McCarthy, M. I., Dermitzakis, E. T., Spector, T. D., \& Mu, T. C. (2011, Feb 3). The architecture of gene regulatory variation across multiple human tissues: the MuTHER study. PLoS Genet, 7(2), e1002003. https://doi.org/10.1371/journal.pgen.1002003

Nyholt, D. R., Yu, C. E., \& Visscher, P. M. (2009, Feb). On Jim Watson's APOE status: genetic information is hard to hide. Eur J Hum Genet, 17(2), 147-149. https://doi.org/10.1038/ejhg.2008.198

Okabe, H., Satoh, S., Kato, T., Kitahara, O., Yanagawa, R., Yamaoka, Y., Tsunoda, T., Furukawa, Y., \& Nakamura, Y. (2001, Mar 1). Genome-wide analysis of gene expression in human hepatocellular carcinomas using cDNA microarray: identification of genes involved in viral carcinogenesis and tumor progression. Cancer Res, 61(5), 2129-2137. https://www.ncbi.nlm.nih.gov/pubmed/11280777

Pilling, L. C., Atkins, J. L., Bowman, K., Jones, S. E., Tyrrell, J., Beaumont, R. N., Ruth, K. S., Tuke, M. A., Yaghootkar, H., Wood, A. R., Freathy, R. M., Murray, A., Weedon, M. N., Xue, L., Lunetta, K., Murabito, J. M., Harries, L. W., Robine, J. M., Brayne, C., Kuchel, G. A., Ferrucci, L., Frayling, T. M., \& Melzer, D. (2016, Mar). Human longevity is influenced by many genetic variants: evidence from 75,000 UK Biobank participants. Aging (Albany NY), 8(3), 547-560. https://doi.org/10.18632/aging.100930

Pilling, L. C., Kuo, C. L., Sicinski, K., Tamosauskaite, J., Kuchel, G. A., Harries, L. W., Herd, P., Wallace, R., Ferrucci, L., \& Melzer, D. (2017, Dec 6). Human longevity: 25 genetic loci associated in 389,166 UK biobank participants. Aging (Albany NY), 9(12), 2504-2520. https://doi.org/10.18632/aging.101334

Porcu, E., Rueger, S., Lepik, K., e, Q. C., Consortium, B., Santoni, F. A., Reymond, A., \& Kutalik, Z. (2019, Jul 24). Mendelian randomization integrating GWAS and eQTL data reveals genetic determinants of complex and clinical traits. Nat Commun, 10(1), 3300. https://doi.org/10.1038/s41467-019-10936-0 
1063

1064

1065

1066

1067

1068

1069

1070

1071

1072

1073

1074

1075

1076

1077

1078

1079

1080

1081

1082

1083

1084

1085

1086

1087

1088

1089

1090

1091

1092

1093

1094

1095

1096

1097

1098

1099

1100

1101

1102

1103

1104

1105

1106

Rall, S. C., Jr., Weisgraber, K. H., \& Mahley, R. W. (1982, Apr 25). Human apolipoprotein E. The complete amino acid sequence. $J$ Biol Chem, 257(8), 4171-4178. https://www.ncbi.nlm.nih.gov/pubmed/7068630

Ryu, S., Atzmon, G., Barzilai, N., Raghavachari, N., \& Suh, Y. (2016, Apr). Genetic landscape of APOE in human longevity revealed by high-throughput sequencing. Mech Ageing Dev, 155, 7-9. https://doi.org/10.1016/j.mad.2016.02.010

Schunkert, H., Konig, I. R., Kathiresan, S., Reilly, M. P., Assimes, T. L., Holm, H., Preuss, M., Stewart, A. F., Barbalic, M., Gieger, C., Absher, D., Aherrahrou, Z., Allayee, H., Altshuler, D., Anand, S. S., Andersen, K., Anderson, J. L., Ardissino, D., Ball, S. G., Balmforth, A. J., Barnes, T. A., Becker, D. M., Becker, L. C., Berger, K., Bis, J. C., Boekholdt, S. M., Boerwinkle, E., Braund, P. S., Brown, M. J., Burnett, M. S., Buysschaert, I., Cardiogenics, Carlquist, J. F., Chen, L., Cichon, S., Codd, V., Davies, R. W., Dedoussis, G., Dehghan, A., Demissie, S., Devaney, J. M., Diemert, P., Do, R., Doering, A., Eifert, S., Mokhtari, N. E., Ellis, S. G., Elosua, R., Engert, J. C., Epstein, S. E., de Faire, U., Fischer, M., Folsom, A. R., Freyer, J., Gigante, B., Girelli, D., Gretarsdottir, S., Gudnason, V., Gulcher, J. R., Halperin, E., Hammond, N., Hazen, S. L., Hofman, A., Horne, B. D., Illig, T., Iribarren, C., Jones, G. T., Jukema, J. W., Kaiser, M. A., Kaplan, L. M., Kastelein, J. J., Khaw, K. T., Knowles, J. W., Kolovou, G., Kong, A., Laaksonen, R., Lambrechts, D., Leander, K., Lettre, G., Li, M., Lieb, W., Loley, C., Lotery, A. J., Mannucci, P. M., Maouche, S., Martinelli, N., McKeown, P. P., Meisinger, C., Meitinger, T., Melander, O., Merlini, P. A., Mooser, V., Morgan, T., Muhleisen, T. W., Muhlestein, J. B., Munzel, T., Musunuru, K., Nahrstaedt, J., Nelson, C. P., Nothen, M. M., Olivieri, O., Patel, R. S., Patterson, C. C., Peters, A., Peyvandi, F., Qu, L., Quyyumi, A. A., Rader, D. J., Rallidis, L. S., Rice, C., Rosendaal, F. R., Rubin, D., Salomaa, V., Sampietro, M. L., Sandhu, M. S., Schadt, E., Schafer, A., Schillert, A., Schreiber, S., Schrezenmeir, J., Schwartz, S. M., Siscovick, D. S., Sivananthan, M., Sivapalaratnam, S., Smith, A., Smith, T. B., Snoep, J. D., Soranzo, N., Spertus, J. A., Stark, K., Stirrups, K., Stoll, M., Tang, W. H., Tennstedt, S., Thorgeirsson, G., Thorleifsson, G., Tomaszewski, M., Uitterlinden, A. G., van Rij, A. M., Voight, B. F., Wareham, N. J., Wells, G. A., Wichmann, H. E., Wild, P. S., Willenborg, C., Witteman, J. C., Wright, B. J., Ye, S., Zeller, T., Ziegler, A., Cambien, F., Goodall, A. H., Cupples, L. A., Quertermous, T., Marz, W., Hengstenberg, C., Blankenberg, S., Ouwehand, W. H., Hall, A. S., Deloukas, P., Thompson, J. R., Stefansson, K., Roberts, R., Thorsteinsdottir, U., O'Donnell, C. J., McPherson, R., Erdmann, J., Consortium, C. A., \& Samani, N. J. (2011, Mar 6). Large-scale association analysis identifies 13 new susceptibility loci for coronary artery disease. Nat Genet, 43(4), 333-338. https://doi.org/10.1038/ng.784

Sebastiani, P., Gurinovich, A., Bae, H., Andersen, S., Malovini, A., Atzmon, G., Villa, F., Kraja, A. T., Ben-Avraham, D., Barzilai, N., Puca, A., \& Perls, T. T. (2017, Oct 12). Four Genome-Wide Association Studies Identify New Extreme Longevity Variants. $J$ Gerontol A Biol Sci Med Sci, 72(11), 1453-1464. https://doi.org/10.1093/gerona/glx027 
Seo, J., Kim, M. H., Hong, H., Cho, H., Park, S., Kim, S. K., \& Kim, J. (2019, Dec 15). MK5 Regulates YAP Stability and Is a Molecular Target in YAP-Driven Cancers. Cancer Res, 79(24), 6139-6152. https://doi.org/10.1158/0008-5472.CAN-19-1339

Shaffer, J. M., \& Smithgall, T. E. (2009, Mar). Promoter methylation blocks FES proteintyrosine kinase gene expression in colorectal cancer. Genes Chromosomes Cancer, 48(3), 272-284. https://doi.org/10.1002/gcc.20638

Stankunas, K., Shang, C., Twu, K. Y., Kao, S. C., Jenkins, N. A., Copeland, N. G., Sanyal, M., Selleri, L., Cleary, M. L., \& Chang, C. P. (2008, Sep 26). Pbx/Meis deficiencies demonstrate multigenetic origins of congenital heart disease. Circ Res, 103(7), 702-709. https://doi.org/10.1161/CIRCRESAHA.108.175489

Timmers, P. R., Mounier, N., Lall, K., Fischer, K., Ning, Z., Feng, X., Bretherick, A. D., Clark, D. W., e, Q. C., Agbessi, M., Ahsan, H., Alves, I., Andiappan, A., Awadalla, P., Battle, A., Bonder, M. J., Boomsma, D., Christiansen, M., Claringbould, A., Deelen, P., van Dongen, J., Esko, T., Fave, M., Franke, L., Frayling, T., Gharib, S. A., Gibson, G., Hemani, G., Jansen, R., Kalnapenkis, A., Kasela, S., Kettunen, J., Kim, Y., Kirsten, H., Kovacs, P., Krohn, K., Kronberg-Guzman, J., Kukushkina, V., Kutalik, Z., Kahonen, M., Lee, B., Lehtimaki, T., Loeffler, M., Marigorta, U., Metspalu, A., van Meurs, J., Milani, L., Muller-Nurasyid, M., Nauck, M., Nivard, M., Penninx, B., Perola, M., Pervjakova, N., Pierce, B., Powell, J., Prokisch, H., Psaty, B. M., Raitakari, O., Ring, S., Ripatti, S., Rotzschke, O., Rueger, S., Saha, A., Scholz, M., Schramm, K., Seppala, I., Stumvoll, M., Sullivan, P., Teumer, A., Thiery, J., Tong, L., Tonjes, A., Verlouw, J., Visscher, P. M., Vosa, U., Volker, U., Yaghootkar, H., Yang, J., Zeng, B., Zhang, F., Agbessi, M., Ahsan, H., Alves, I., Andiappan, A., Awadalla, P., Battle, A., Bonder, M. J., Boomsma, D., Christiansen, M., Claringbould, A., Deelen, P., van Dongen, J., Esko, T., Fave, M., Franke, L., Frayling, T., Gharib, S. A., Gibson, G., Hemani, G., Jansen, R., Kalnapenkis, A., Kasela, S., Kettunen, J., Kim, Y., Kirsten, H., Kovacs, P., Krohn, K., KronbergGuzman, J., Kukushkina, V., Kutalik, Z., Kahonen, M., Lee, B., Lehtimaki, T., Loeffler, M., Marigorta, U., Metspalu, A., van Meurs, J., Milani, L., Muller-Nurasyid, M., Nauck, M., Nivard, M., Penninx, B., Perola, M., Pervjakova, N., Pierce, B., Powell, J., Prokisch, H., Psaty, B. M., Raitakari, O., Ring, S., Ripatti, S., Rotzschke, O., Rueger, S., Saha, A., Scholz, M., Schramm, K., Seppala, I., Stumvoll, M., Sullivan, P., Teumer, A., Thiery, J., Tong, L., Tonjes, A., Verlouw, J., Visscher, P. M., Vosa, U., Volker, U., Yaghootkar, H., Yang, J., Zeng, B., Zhang, F., Shen, X., Esko, T., Kutalik, Z., Wilson, J. F., \& Joshi, P. K. (2019, Jan 15). Genomics of 1 million parent lifespans implicates novel pathways and common diseases and distinguishes survival chances. Elife, 8. https://doi.org/10.7554/eLife.39856

Võsa, U., Claringbould, A., Westra, H. J., Bonder, M. J., Deelen, P., \& Franke, L. (2018). Unraveling the polygenic architecture of complex traits using blood eQTL meta-analysis. https://doi.org/https://doi.org/10.1101/447367

Wang, Y., Wang, J., Zhang, L., Karatas, O. F., Shao, L., Zhang, Y., Castro, P., Creighton, C. J., \& Ittmann, M. (2017, Aug 15). RGS12 Is a Novel Tumor-Suppressor Gene in African 
American Prostate Cancer That Represses AKT and MNX1 Expression. Cancer Res, 77(16), 4247-4257. https://doi.org/10.1158/0008-5472.CAN-17-0669

1155

1156

1157

1158

1159

1160

1161

1162

1163

1164

1165

1166

1167

1168

1169

1170

1171

1172

1173

1174

1175

1176

1177

1178

1179

1180

1181

1182

1183

1184

1185

1186

1187

1188

1189

1190

Wei, M., Brandhorst, S., Shelehchi, M., Mirzaei, H., Cheng, C. W., Budniak, J., Groshen, S., Mack, W. J., Guen, E., Di Biase, S., Cohen, P., Morgan, T. E., Dorff, T., Hong, K., Michalsen, A., Laviano, A., \& Longo, V. D. (2017, Feb 15). Fasting-mimicking diet and markers/risk factors for aging, diabetes, cancer, and cardiovascular disease. Sci Transl Med, 9(377). https://doi.org/10.1126/scitranslmed.aai8700

Westra, H. J., Peters, M. J., Esko, T., Yaghootkar, H., Schurmann, C., Kettunen, J., Christiansen, M. W., Fairfax, B. P., Schramm, K., Powell, J. E., Zhernakova, A., Zhernakova, D. V., Veldink, J. H., Van den Berg, L. H., Karjalainen, J., Withoff, S., Uitterlinden, A. G., Hofman, A., Rivadeneira, F., Hoen, P. A. C., Reinmaa, E., Fischer, K., Nelis, M., Milani, L., Melzer, D., Ferrucci, L., Singleton, A. B., Hernandez, D. G., Nalls, M. A., Homuth, G., Nauck, M., Radke, D., Volker, U., Perola, M., Salomaa, V., Brody, J., Suchy-Dicey, A., Gharib, S. A., Enquobahrie, D. A., Lumley, T., Montgomery, G. W., Makino, S., Prokisch, H., Herder, C., Roden, M., Grallert, H., Meitinger, T., Strauch, K., Li, Y., Jansen, R. C., Visscher, P. M., Knight, J. C., Psaty, B. M., Ripatti, S., Teumer, A., Frayling, T. M., Metspalu, A., van Meurs, J. B. J., \& Franke, L. (2013, Oct). Systematic identification of trans eQTLs as putative drivers of known disease associations. Nat Genet, 45(10), 1238-1243. https://doi.org/10.1038/ng.2756

Willcox, B. J., Donlon, T. A., He, Q., Chen, R., Grove, J. S., Yano, K., Masaki, K. H., Willcox, D. C., Rodriguez, B., \& Curb, J. D. (2008, Sep 16). FOXO3A genotype is strongly associated with human longevity. Proc Natl Acad Sci U S A, 105(37), 13987-13992. https://doi.org/10.1073/pnas.0801030105

Zeng, Y., Nie, C., Min, J., Liu, X., Li, M., Chen, H., Xu, H., Wang, M., Ni, T., Li, Y., Yan, H., Zhang, J. P., Song, C., Chi, L. Q., Wang, H. M., Dong, J., Zheng, G. Y., Lin, L., Qian, F., Qi, Y., Liu, X., Cao, H., Wang, Y., Zhang, L., Li, Z., Zhou, Y., Wang, Y., Lu, J., Li, J., Qi, M., Bolund, L., Yashin, A., Land, K. C., Gregory, S., Yang, Z., Gottschalk, W., Tao, W., Wang, J., Wang, J., Xu, X., Bae, H., Nygaard, M., Christiansen, L., Christensen, K., Franceschi, C., Lutz, M. W., Gu, J., Tan, Q., Perls, T., Sebastiani, P., Deelen, J., Slagboom, E., Hauser, E., Xu, H., Tian, X. L., Yang, H., \& Vaupel, J. W. (2016, Feb 25). Novel loci and pathways significantly associated with longevity. Sci Rep, 6, 21243. https://doi.org/10.1038/srep21243 